\title{
FAME LAW: REQUIRING PROOF OF NATIONAL FAME IN TRADEMARK LAW
}

\author{
Xuan-Thao Nguyen*
}

\begin{abstract}
The public has always been infatuated with fame. Trademark law likewise has a long history of infatuation with fame. Protecting the fame embodied in a trademark against dilutive use by others has not been easy. The difficulty stems from the wording of the statute and judicial failure to understand the "fame" requirement. The fundamental question centers on what level of fame is required for the property-like protection against subsequent uses that dilute the famous trademark. This Article argues for national fame to be the requisite requirement for property-like anti-dilution protection under trademark law. The Article recommends that the proof of national fame should be survey evidence showing at least seventy percent of the general consuming public across the United States recognizing the trademark. Bestowing trademarks property-like protection to those with proof of national fame strikes a reasonable balance between the interests of trademark owners and the public.
\end{abstract}

\section{INTRODUCTION}

Is NYC Triathlon ${ }^{1}$ a name with fame status which entitles it to special protection under trademark law? How many consumers in the United States recognize the AMERICA'S TEAM ${ }^{2}$ or 5-HOUR ENERGY ${ }^{3}$

* Professor of Law, SMU Dedman School of Law; Former IP Associate, Fried Frank Harris Shriver \& Jacobson (NYC) and Pryor Cashman Sherman \& Flynn (NYC). This Article was made possible by the John P. Hall Endowed Faculty Research Fund. Many thanks to my valuable research assistants Pei-Chih "Peggy" Ho, Elizabeth Polk, and Michelle Tran, SMU Dedman School of Law Class of 2011. As always, special thanks to Erik Darwin Hille and Khai-Leif Nguyen-Hille for their love, patience and support.

1 See N.Y.C. Triathlon, LLC v. NYC Triathlon Club, Inc., 704 F. Supp. 2d 305, 311 (S.D.N.Y. 2010).

2 See Dall. Cowboys Football Club, Ltd. v. America's Team Props., Inc., 616 F. Supp. 2d 622 (N.D. Tex. 2009). 
trademarks? Has CHEM-DRY ${ }^{4}$ achieved the requisite level of fame for broad protection? Where is KU or KANSAS UNIVERSITY 5 in the spectrum of fame? Have these trademarks attained enough fame to be deemed sufficiently famous for broad nationwide protection? How many people in the general consuming public actually recognize any of these trademarks? ${ }^{6}$

Fame is defined as "the condition of being known or talked about by many people, [especially] on account of notable achievement." 7 The public has always been infatuated with fame, as images of and headlines about famous movie stars, super models, athletes, politicians, and celebrity chefs appear in online and offline media at any given time. ${ }^{8}$ The public knows well that fame is not eternal. ${ }^{9}$ Fame fades with time and requires much effort to forestall it from fading. ${ }^{10}$ Trademarks with fame share the same problems as celebrities, as many once well-known trademarks have either declined or disappeared from the public view. ${ }^{11}$

3 See Innovation Ventures LLC v. Hoodiamax USA, No. CV 09-5426 AHM, 2010 WL 3171318 (C.D. Cal. Aug. 9, 2010).

4 See Harris Research, Inc. v. Lydon, 505 F. Supp. 2d 1161, 1164-65 (D. Utah 2007).

5 See Univ. of Kan. v. Sinks, 644 F. Supp. 2d 1287 (D. Kan. 2008).

6 For example, the trademark LEXIS is widely recognized by lawyers and law students as one of the main legal databases, but the mark is hardly recognized by the general consuming public. See Mead Data Cent., Inc. v. Toyota Motor Sales, U.S.A., Inc., 875 F.2d 1026 (2d Cir. 1989) (noting that although seventy-six percent of attorneys recognized the trademark LEXIS for computer-assisted legal research service, only one percent of the general population make the correct association, and half of this one percent were attorneys or accountants).

7 THE OXFORD COLlEGE DiCTIONARY 495 (2d ed. 2007).

8 Samantha Barbas, The Death of the Public Disclosure Tort: A Historical Perspective, 22 YALE J.L. \& HUMAN. 171, 193-94 (2010) (tracing the history of modern embrace of fame and noting that by "1927, the celebrity pantheon, as reflected in the content of a typical issue of the Sunday New York Times, included Broadway producers, literary figures, movie stars, society personalities, sports players, the owners of baseball teams, screenwriters, and chefs, among others"); Justin Pats, The Show Must Go On: An Egalitarian Approach to Descendibility as Applied to a Prospective Federal Persona Right Statutes, 35 N. KY. L. REV. 37, 51 (2008) (noting that celebrities with high earning power are individuals "who are often catapulted to fame, and notoriety, not by their own accomplishments, but rather by the public's oft-unpredictable adoration and infatuation for them").

9 The obsession with achieving eternal fame can be seen in the Hippocratic Oath. See Lisa R. Hasday, The Hippocratic Oath as Literary Text: A Dialogue Between Law and Medicine, 2 YALE J. HEALTH POL'Y L. \& ETHICS 299, 304 (2002) (noting that the “[o]ath's closing words seem to indicate that the Hippocratic physician is more concerned about whether he will enjoy eternal fame than whether his patients will live life to the fullest").

10 See Memphis Dev. Found. v. Factors, Etc., Inc., 616 F.2d 956, 959 (6th Cir. 1980) ("Fame often is fortuitous and fleeting. It always depends on the participation of the public in the creation of an image. It usually depends on the communication of information about the famous person by the media."); see also John Bronsteen et al., Welfare as Happiness, 98 GEO. L.J. 1583, 1625 (2010) (stating that fame "and recognition have fleeting hedonic consequences"); Sheldon W. Halpern, The Right of Publicity: Commercial Exploitation of the Associative Value of Personality, 39 VAND. L. REV. 1199, 1224 (1986) (noting that courts in addressing fame are moved "by the ephemeral nature of fame").

11 See generally Robert Brauneis \& Paul Heald, Trademark Infringement, Trademark Dilution, and the Decline in Sharing of Famous Brand Names: An Introduction and Empirical 
Similarly, trademark law has a long history of infatuation with fame. ${ }^{12}$ The idea of protecting famous trademarks has been in existence for many years. ${ }^{13}$ Internationally, the concept of protection for wellknown ${ }^{14}$ trademarks is evident in the old and influential Paris Convention for the Protection of Industrial Property. ${ }^{15}$ In the United States, the desire to protect famous trademarks within domestic boundaries against

Study, 59 BUFF. L. REV. (forthcoming 2011) (investigating the decline of famous trademarks among business and positing a host of non-legal factors contributing to the decline); Doris Estelle Long, Is Fame All There Is? Beating Global Monopolists at Their Own Marketing Game, 40 GEO. WASH. INT'L L. REV. 123, 142 (2008) (observing that "a mark that is famous today may not be famous tomorrow [and that] [s]uch fleeting fame is even more likely with the global internet, where fads can rise quickly and just as quickly disappear").

12 Alexis Weissberger, Is Fame Alone Sufficient to Create Priority Rights: An International Perspective on the Viability of the Famous/Well-Known Marks Doctrine, 24 CARDOZO ARTS \& ENT. L.J. 739, 740 (2006) (noting the international struggle in addressing fame for the crossborder protection of well-known trademarks).

13 Blake W. Jackson, Notorious: The Treatment of Famous Trademarks in America and How Protection Can Be Ensured, 3 J. Bus. ENTREPRENEURSHIP \& L. 61, 65 (2009) (discussing the U.S. and international attempts to protect famous foreign trademarks).

14 Hearings on the Federal Trademark Dilution Act of 1995 Before the Subcomm. on Courts, the Internet, and Intellectual Property of the House Comm. on the Judiciary, 104th Cong. (1995) (statement of Philip G. Hampton II, Assistant Comm'r for Trademarks), available at 1995 WL 435751, at *3 (F.D.C.H. 1995) ("The United States is obligated to protect famous marks pursuant to Article 6bis of the Paris Convention ..."). Article 6bis, however, refers to "well-known" marks and the Paris Convention does not afford anti-dilution protection for such marks. See David S. Welkowitz, Famous Marks Under TDRA, 99 TRADEMARK REP. 983, 986 n.14 (2009).

15 See Paris Convention for the Protection of Industrial Property, art. 6bis, May 4, 1970, 21 U.S.T. 1583, 828 U.N.T.S. 305, available at $1970 \mathrm{WL} 104436$. The provision for protection of famous trademark is Article 6bis of the 1925 version of the Paris Convention:

Marks: Well-Known Marks

(1) The countries of the Union undertake, ex officio if their legislation so permits, or at the request of an interested party, to refuse or to cancel the registration, and to prohibit the use, of a trademark which constitutes a reproduction, an imitation, or a translation, liable to create confusion, of a mark considered by the competent authority of the country of registration or use to be well known in that country as being already the mark of a person entitled to the benefits of this Convention and used for identical or similar goods. These provisions shall also apply when the essential part of the mark constitutes a reproduction of any such well-known mark or an imitation liable to create confusion therewith.

(2) A period of at least five years from the date of registration shall be allowed for requesting the cancellation of such a mark. The countries of the Union may provide for a period within which the prohibition of use must be requested.

(3) No time limit shall be fixed for requesting the cancellation or the prohibition of the use of marks registered or used in bad faith.

The current International Agreement on Trade-Related Aspects of Intellectual Property Rights (TRIPS) incorporates the Paris Article 6bis into TRIPS Article 16.3: "Article 6bis of the Paris Convention (1967) shall apply, mutatis mutandis, to goods or services which are not similar to those in respect of which a trademark is registered, provided that use of that trademark in relation to those goods or services would indicate a connection between those goods or services and the owner of the registered trademark and provided that the interests of the owner of the registered trademark are likely to be damaged by such use." Agreement on Trade-Related Aspects of Intellectual Property Rights, Apr. 15, 1994, 1869 U.N.T.S. 299, available at http://www.wto.org/english/docs_e/legal_e/27-trips.pdf. 
dilutive use ${ }^{16}$ can be traced back to $1988,{ }^{17}$ though courts had recognized earlier that some trademarks possessed a high level of recognition among consumers and thus should be entitled to broader protection. ${ }^{18}$ The protection enables the owner of a famous trademark to enjoin others from using the mark on noncompeting goods and services. For example, using the KODAK trademark for cameras may prevent its use on bicycles, as using the ROLLS-ROYCE name for automobiles may prohibit its use on pens or tubes. ${ }^{19}$

Protecting the fame embodied in a trademark against dilutive use by others has an uneasy and torturous history in trademark dilution law. ${ }^{20}$ The history spans from the 1927 law review article penned by

16 The current definition for dilutive use is in the Federal Trademark Revision Act of 2006: "Dilution by blurring" is defined as an "association arising from the similarity between a mark or trade name and a famous mark that impairs the distinctiveness of the famous mark" and "dilution by tarnishment" means an "association arising from the similarity between a mark or trade name and a famous mark that harms the reputation of the famous mark." 15 U.S.C. § 1125(c)(2)(B) \& (C) (2006).

17 Welkowitz, supra note 14, at 985 (stating that "[f]ame enters the picture in 1987, when the United States Trademark Association (as the International Trademark Association was then called) included a provision for federal dilution protection of famous (registered) marks as part of its proposal to amend the Lanham Act").

18 See, e.g., Dan Robbins \& Assocs. v. Questor Corp., 599 F.2d 1009, 1013 (C.C.P.A. 1979) ("A mark's fame can influence its breadth of protection."); Tiffany \& Co. v. Tiffany Tile Corp., 345 F.2d 214, 215 (C.C.P.A. 1965) (reversing the Trademark Trial and Appeal Board's decision upon recognizing that the trademark TIFFANY is a well-known trademark and permitting Tiffany \& Co. to oppose the registration of the trademark TIFFANY'S TILE for ceramic tiles); see also Telemed Corp. v. Tel-Med, Inc., 588 F.2d 213, 219 (7th Cir. 1978) ("A mark that is strong because of its fame or its uniqueness is more likely to be associated in the public mind with a greater breadth of products or services than is a mark that is weak because it is very much like similar marks."); James Burrough Ltd. v. Sign of the Beefeater, Inc., 572 F.2d 574, 577 (7th Cir. 1978) ("When a particular mark is famous, . . . as is true in the case of Beefeater Gin, it is error to limit the effect of the mark to a competing liquor product, or even to a restaurant which sells liquor.").

19 Courts have long pondered the question of "whether the use of a famous brand on a noncompeting product constitutes an actionable infringement." See Phila. Storage Battery Co. v. Mindlin, 296 N.Y.S. 176, 178 (N.Y. Sup. Ct. 1937). The Mindlin court noted that the protection for famous marks had been broader:

The ambit of protection is constantly being widened. The adoption of 'Kodak' for cameras precludes its use on bicycles; 'Rolls-Royce,' the name of an automobile, may not be appropriated for radio tubes; 'Times' as a brand for bicycles may be restrained by the proprietor of a newspaper bearing that name; 'Waterman' as a mark for razor blades may be interdicted at the suit of the fountain pen company; the use of 'Dunhill,' the famous brand for smokers' supplies, on shirts constitutes an infringement; the same mark may not be used on liniment and soap; automobiles and tires; food products and oleomargarine; upon electrical appliances and spark plugs; upon cooking utensils and wash boilers; or upon mineral oil and figs.

Id. at 180 (internal citations omitted).

20 Laura R. Bradford, Emotion, Dilution, and the Trademark Consumer, 23 BERKELEY TECH. L.J. 1227, 1231 n.10 (2008) (noting that Massachusetts became the first state to extend antidilution protection to trademarks in 1947 and that the United States did not have any federal trademark dilution law until the first successful legislation in 1995); see also Welkowitz, supra note 14, at 984-93 (providing a history of fame and anti-dilution law). 
Frank Schechter, 21 "the father of the dilution theory," 22 to the enactments of various state statutes with different requirements relating to fame, ${ }^{23}$ the Federal Trademark Dilution Act of 1995 (FTDA), ${ }^{24}$ and finally the Supreme Court's Moseley v. V Secret Catalogue, Inc. opinion, ${ }^{25}$ which led to the revamping of the federal dilution law in 2006 as a direct response to the decision. ${ }^{26}$

The last major overhaul in fame jurisprudence for famous trademark protection was the enactment of the Federal Trademark Dilution Revision Act of 2006 (TDRA). ${ }^{27}$ Though many praised the passage of the TDRA, ${ }^{28}$ five years later courts continue to struggle with antidilution law protection for famous trademarks, ${ }^{29}$ as seen in the decisions

21 Frank L. Schechter, The Rational Basis of Trademark Protection, 40 HARV. L. REV. 813, 824-25 (1927) (suggesting that, even with non-competing goods or services and without evidence of likelihood of confusion, the junior user's mark may "whittle away" the distinctiveness of the senior user's mark).

22 Mead Data Cent., Inc. v. Toyota Motor Sales, U.S.A., Inc., 875 F.2d 1026, 1028 (2d Cir. 1989).

23 The United States Trademark Association, later renamed as the International Trademark Association, drafted the 1964 and 1992 versions of the Model State Trademark Bill for protection of famous trademarks against dilution. Mark H. Anania, Note, The Plight of Small Business Trademark Holders, 59 RUTGERS L. REV. 565, 588-90 (2007). Fourteen states adopted the 1964 Model Bill, which does not require "fame" for the trademark seeking anti-dilution protection. Id. at 588 (noting that the fourteen states include Alabama, California, Delaware, Florida, Georgia, Louisiana, Maine, Massachusetts, Missouri, New Hampshire, New York, Oregon, Rhode Island, and Texas). Twenty-three states adopted the 1992 Model Bill, which requires that the trademark must be famous. Id. at 589 (listing the twenty-three states of Alaska, Arizona, Arkansas, Connecticut, Hawaii, Idaho, Illinois, Kansas, Iowa, Minnesota, Mississippi, Montana, Nebraska, Nevada, New Jersey, New Mexico, Pennsylvania, South Carolina, Tennessee, Utah, Washington, West Virginia, and Wyoming).

24 See Federal Trademark Dilution Act of 1995, Pub. L. No. 104-98, 109 Stat. 985 (1996), amended by Trademark Dilution Revision Act of 2006, 15 U.S.C. § 1125 (2006) (originally enacted as Trademark Act of 1946, ch. 540, § 43, 60 Stat. 427 (1946)).

25 See Moseley v. V Secret Catalogue, Inc., 537 U.S. 418 (2003) (holding that the FTDA requires proof of actual dilution, not likelihood of dilution).

26 See Blake R. Bertagna, Poaching Profits: An Examination of the Ability of a Trademark Owner to Recover an Infringer's Profits Under the Lanham Act as Amended in 1999, 16 TEX. INTELL. PROP. L.J. 257, 265-66 (2008) (recounting the development of the federal dilution law); Matthew J. Slowik, Ahead of the Curve? The Effect of the Trademark Dilution Revision Act of 2006 on the Federal Circuit, 18 FED. CIR. B.J. 349, 349 (2009) (explaining how the TDRA was the legislative response to the Supreme Court's ruling on proof of dilution of famous trademarks).

27 Some commentators have provided assessment of the TDRA after the first year of its enactment. Barton Beebe, The Continuing Debacle of U.S. Antidilution Law: Evidence from the First Year of Trademark Dilution Revision Act Case Law, 24 SANTA ClaRA COMPUTER \& HigH TECH. L.J. 449, 450 (2008) (concluding that after the first year of the new law, "antidilution law continues to have no appreciable effect on the outcomes of federal trademark cases or the remedies issuing from those outcomes"); Clarisa Long, Dilution, 106 CoLUM. L. REV. 1029, 1031 (2006) (noting that, as of 2006, federal judicial enforcement of dilution law was rather weak).

28 See Scot A. Duvall, The Trademark Dilution Revision Act of 2006: Balanced Protection for Famous Brands, 97 TRADEMARK REP. 1252, 1255 (2007) (asserting that the TDRA "balances the legitimate concerns of owners of famous brands and newcomers to the marketplace" and "brings much-needed balance and clarity to the Lanham Act's treatment of this oft-maligned area of the law").

$$
29 \text { See infra Part III. }
$$


where courts erroneously held that NYC TRIATHLON, AMERICA'S TEAM, 5-HOUR ENERGY, and CHEM-DRY, among other marks, are famous for the broad protection under TDRA. ${ }^{30}$ Judicial struggle with the "fame" requirement is due to a host of factors. ${ }^{31}$ The difficulty stems from the wording of the statute and judicial failure to grasp legislative history and intent in interpreting the statute with respect to "fame." 32

The fundamental question centers on what level of fame is required for protection against subsequent uses that dilute the distinctiveness of the famous trademark? ${ }^{33}$ In other words, how much "fame" is deemed sufficient to satisfy "famousness" under current U.S. trademark antidilution law? ${ }^{34}$

This Article argues that national fame as recognized by at least seventy percent of the U.S. general consuming public must be the requisite requirement for protection under the TDRA. The heightened level of fame requirement functions as a gatekeeper to prevent widespread of treating trademarks purely as property in trademark jurisprudence. It is consistent with congressional intent for the few deserving trademarks with broad property protection and with the language of the statute that states the mark must be widely known by the general consuming public.

This Article will proceed as follows. Part I will trace the fascination with fame in trademark law and the rise and fall of the "big fish in a small pond" theory to protect trademarks known in niches. Part II will discuss the TDRA in which fame is defined for anti-dilution protection. Five years after the passage of the new law, courts are still struggling with what fame is. Part III will identify and discuss the erroneous decisions on fame rendered by courts. Part IV will provide possible explanations for judicial shortcomings and a solution that would rectify the situation and is consistent with congressional intent under the statute. The Article suggests that survey evidence showing at least seventy percent of the general consuming public across the United States recognizes a trademark is necessary to establish national fame for property-like protection of the famous trademark. The Article concludes that bestowing trademarks property-like protection to those with proof of national fame strikes a reasonable balance between the interests of trademark owners and the public.

30 See infra Part III.

31 See infra Part IV.

32 See cases cited and discussion infra Parts III, IV.

33 Welkowitz, supra note 14, at 993-96 (addressing the reasons why fame is required for antidilution protection).

34 Internationally, the fame question is a struggle for nations to address under the famous or well-known trademark doctrine. Jackson, supra note 13, at 65 (stating that the problem of protecting foreign famous trademark is compounded by not having a test to measure fame and that "[w]ithout a good test of determining which trademarks are famous, and therefore deserving of protection, the famous trademarks doctrine struggles"). 


\section{The Death OF The “Big Fish in a SMall Pond” Fame LaW}

The fascination with fame in trademark law lays the foundation for courts to formulate the much-maligned "big fish in a small pond" theory to protect certain trademarks. ${ }^{35}$ Under the theory, a name is deemed to have sufficient fame to award it "famous" status if it is recognized in a particular industry or geographical area. ${ }^{36}$ The owner of the "famous" name has the right to exclude others from using the name on unrelated products or services. ${ }^{37}$ The owner can enjoy the right to exclude even without proof of likelihood of consumer confusion caused by use of the famous name by others on noncompeting goods. ${ }^{38}$

Embracing the "big fish in a small pond" theory, many courts expanded the rights of holders of trademarks that are not household names. For example, the Third Circuit in Times Mirror Magazines, Inc. v. Las Vegas Sports News, L.L.C. held that the trademark THE SPORTING NEWS was famous in the sports periodicals arena in Las Vegas. ${ }^{39}$

35 See Times Mirror Magazines, Inc. v. Las Vegas Sports News, L.L.C., 212 F.3d 157, 173 74 (3d Cir. 2000) (Barry, J., dissenting) (criticizing the majority in this case for its approval of the 'big fish in a small pond' theory of trademark dilution, which may "overrun" existing trademark infringement law and injure legitimate competition in the marketplace). See also the criticism offered by Courtland L. Reichman, State and Federal Trademark Dilution, 17 FRANCHISE L.J. 111, 133 (1998):

Courts approving the "big fish in a small pond" theory of trademark dilution fail to recognize that it threatens to overrun trademark infringement law. Trademark infringement law permits similar, or even identical, marks to coexist on non-competing goods. If even a locally famous mark can preclude all other marks in every channel of trade, then conceivably every trademark can be used to create a monopoly in a word or symbol-a proposition clearly contrary to the intent and practice of trademark law. It is possible to find virtually any mark to be "famous" within some market, depending on how narrowly that market is defined.

36 See Wedgwood Homes, Inc. v. Lund, 659 P.2d 377 (Or. 1983) (en banc) (protecting a local trademark known only in the eastern part of one county in Oregon).

37 For example, applying the "big fish in a small pond theory," the Oregon Supreme Court in Wedgwood Homes held that the owner of a local trademark is entitled to protection under dilution law against the use of that mark on unrelated goods. Id. The Court could "see no reason why marks of national renown should enjoy protection while local marks should not. A small local firm may expend efforts and money proportionately as great as those of a large firm in order to establish its mark's distinct quality. In both situations the interest to be protected and the damage to be prevented are the same." Id. at 381 .

38 Dreyfus Fund, Inc. v. Royal Bank of Can., 525 F. Supp. 1108, 1123 (S.D.N.Y. 1981) ("[T]he federal courts seem ready at this point to protect a senior user of a suggestive mark from potentially serious harm caused by dilution, where the alleged infringer's use is in connection with noncompeting goods that are related to the senior user's goods."). But see, e.g., Holiday Inns, Inc. v. Holiday Out in Am., 481 F.2d 445, 450 (5th Cir. 1973) (rejecting Holiday Inns's dilution argument that even where "there is no likelihood of confusion of the products or source[], ... the use of the trademark by the subsequent user will lessen the uniqueness of the prior user's mark with the possible future result that a strong mark may become a weak mark").

39 See Times Mirror Magazines, 212 F.3d at 169 (holding that the district court did not err by finding that the SPORTING NEWS trademark is famous in its sports news market in Las Vegas, 
Similarly, in Binney \& Smith v. Rose Art Industries, the district court found that the color scheme of Crayola has achieved sufficient fame to be deemed famous, citing hundreds of millions of advertisement expenditures in the last forty years. ${ }^{40}$ Additionally, the Seventh Circuit extended the niche fame of trademarks to trade dress- the look and feel or packaging of a product or service. ${ }^{41}$ Specifically, the Seventh Circuit in Syndicate Sales, Inc. v. Hampshire Paper Corp. held that the trade dress of plastic baskets used for floral bouquets at funerals was famous in its niche market in which the defendant had adopted a similar trade dress. 42

Consequently, the Restatement (Third) of Unfair Competition, in restating famous trademark law, proclaimed that "[a] mark that is highly distinctive only to a select class or group of purchasers may be protected from diluting uses directed at that particular class or group." 43 Reinforcing the niche fame doctrine, the Fifth Circuit in Advantage Rent- $A$ Car, Inc. v. Enterprise Rent-A-Car, Co. held that the owner of a trademark needs only to prove that the trademark is famous within the car rental market, not in the broader market. ${ }^{44}$ Likewise, the Ninth Circuit in Avery Dennison Corp. v. Sumpton recognized fame in a localized trading market or a specialized market segment for the purpose of protecting famous trademarks under dilution law. ${ }^{45}$

The above cases and other similar cases decided by district and circuit courts across the nation ${ }^{46}$ raised some concerns. The cases were not

and is therefore entitled to protection from the defendant's use of a similar trademark in the same market), cert. denied, 531 U.S. 1071 (2001)

40 See Binney \& Smith v. Rose Art Indus., 60 U.S.P.Q.2d 2000 (E.D. Pa. 2001).

41 See generally Two Pesos, Inc. v. Taco Cabana, Inc., 505 U.S. 763 (1992) (addressing trade dress protection for the look and feel of a fast food restaurant); Xuan-Thao Nguyen, Should It Be a Free for All? The Challenge of Extending Trade Dress Protection to the Look and Feel of Web Sites in the Evolving Internet, 49 AM. U. L. REV. 1233 (2000).

42 Syndicate Sales, Inc. v. Hampshire Paper Corp., 192 F.3d 633, 640 (7th Cir. 1999) (" $[\mathrm{N}]$ iche-market renown is a factor indicating fame [in] a context like the one here, in which the plaintiff and defendant are using the mark in the same or related markets.").

43 RestATEMENT (THIRD) OF UNFAIR COMPETITION $§ 25 \mathrm{cmt}$. e (1995).

44 Advantage Rent-A-Car, Inc. v. Enterprise Rent-A-Car, Co., 238 F.3d 378, 380 (5th Cir. 2001) ("Enterprise needed only to show that its 'We'll Pick You Up' mark is famous within the car rental industry, not in a broader market.").

45 Avery Dennison Corp. v. Sumpton, 189 F.3d 868, 877-78 (9th Cir. 1999) (holding that "fame in a localized trading area may meet" the fame requirement of the dilution statute as may fame in a specialized market segment when the "diluting uses are directed narrowly at the same market segment").

46 See Thane Int'l, Inc. v. Trek Bicycle Corp., 305 F.3d 894 (9th Cir. 2002); Advantage RentA-Car, 238 F.3d at 381; Rhee Bros. v. Han Ah Reum Corp., 178 F. Supp. 2d 525 (D. Md. 2001); NBBJ E. Ltd. P'ship v. NBBJ Training Acad., Inc., 201 F. Supp. 2d 800 (S.D. Ohio 2001); Simon Prop. Grp. v. mySimon, Inc., No. IP 99-1195-C-H/S, 2000 WL 1206575 (S.D. Ind. Aug. 3, 2000); Michael Caruso \& Co. v. Estefan Enters., 994 F. Supp. 1454, 1463 (S.D. Fla. 1998), aff'd, 166 F.3d 353 (11th Cir. 1998); King of the Mountain Sports, Inc. v. Chrysler Corp., 968 F. Supp. 568, 578 (D. Colo. 1997), aff'd, 185 F.3d 1084 (10th Cir. 1999); Golden Bear Int'l, Inc. v. Bear U.S.A., Inc., 969 F. Supp. 742,749 (N.D. Ga. 1996); cf. Mead Data Central, Inc. v. Toyota Motor 
about unfair competition behavior engaged by the defendants or the confusion suffered by the consumer and the harmed incurred by owners of the trademarks. ${ }^{47}$ The courts, by extending protection for fame, treated fame embodied in a trademark as property in gross. ${ }^{48}$ These concerns led some courts to limit niche fame protection to only when the defendant used a similar mark within the same niche. ${ }^{49}$ For example, the Ninth Circuit in Thane International, Inc. v. Trek Bicycle Corp. found that TREK is known among bicycle enthusiasts but not stationary-exercise machine users, and therefore TREK's fame does not qualify for the famousness requirement for protection beyond the niche market under the then trademark dilution law. ${ }^{50}$

Other courts expressed their skepticism towards the expanding rights bestowed on marks that have "brief fame" in a small niche market or a "small segment of the population." 51 They questioned whether such marks should possess the enormous power to prohibit all other uses in all industries throughout the country. ${ }^{52}$ They, not surprisingly, rejected the niche fame and required that fame must be established nationwide in order for a name or trademark to be deemed famous. ${ }^{53}$ Some courts

Sales, Inc., 875 F.2d 1026, 1031 (2d Cir. 1989).

47 See Kenneth L. Port, Trademark Dilution in Japan, 4 Nw. J. TECH. \& INTELL. Prop. 228, 228 (2006) ("Trademark dilution is a right awarded to famous trademark holders to prevent the use of the same or similar marks on non-competing goods or services."); Steven Wilf, The Making of the Post-War Paradigm in American Intellectual Property Law, 31 CoLuM. J.L. \& ARTS 139, 171 (2008) ("Dilution doctrine represented a shift from a tort model to a proprietary model of trademark. Trademarks had been transformed into a distinct form of property with uncanny psychological power.").

48 See Avery Dennison Corp., 189 F.3d at 875 (stating that under trademark dilution law, the protection for famous trademarks "tread[s] very close to granting 'rights in gross' in a trademark," thereby hampering competition and the marketing of new products).

$49 I d$. at $877-78$ (explaining that the statute protects a mark only when a mark is famous within a niche market and the alleged diluter uses the mark within that niche); Times Mirror Magazines, Inc. v. Las Vegas Sports News, L.L.C., 212 F.3d 157, 164 (3d Cir. 2000) ("We are persuaded that a mark not famous to the general public is nevertheless entitled to protection from dilution where both the plaintiff and defendant are operating in the same or related markets, so long as the plaintiff's mark possesses a high degree of fame in its niche market.").

50 Thane Int'l, 305 F.3d at 910 ("[T] to find that TREK is a famous mark within the narrow market segment devoted to non-stationary bicycle production and sales. But there is no reason to expect that the typical purchaser of stationary exercise machines-particularly those who buy their exercise machines as a result of seeing television infomercials-buys bicycles or bicycle-related products, reads bicycle magazines or watches bicycle competitions on television, any more than anybody else does. That the mark 'TREK' is famous with bicycle enthusiasts is therefore of little pertinence in gauging the fame of the mark in the market segment occupied by Thane, the junior user.").

51 TCPIP Holding Co. v. Haar Commc'ns, Inc., 244 F.3d 88, 99 (2d Cir. 2001) (noting that anti-dilution at the federal level is not "intended to confer on marks that have enjoyed only brief fame in a small part of the country, or among a small segment of the population").

52 Id. ("It seems most unlikely that Congress intended to confer on marks that have enjoyed only brief fame in a small part of the country, or among a small segment of the population, the power to enjoin all other users throughout the nation in all realms of commerce.").

53 See generally id. See also Heidi Ott A.G. v. Target Corp., 153 F. Supp. 2d 1055 (D. Minn. 2001); Michael Caruso \& Co. v. Estefan Enters., 994 F. Supp. 1454, 1454 (S.D. Fla. 1998); Avery 
articulated that only marks that have achieved "fame among the general consuming public," 54 a "substantial degree of fame," 55 or are approaching the high degree of fame enjoyed by "household" names such as "Dupont, Buick, or Kodak" 56 are qualified for broad, expansive national protection against free-riders and diluters of the famous trademarks. ${ }^{57}$

In summary, the development of jurisprudence on fame, as illustrated above, reveals an uneasy history of determining the appropriate level of fame for an actionable claim against trademark diluters. Prior to 2006, Congress did not include a definition of fame for judicial determination of whether a trademark qualifies as famous for anti-dilution purposes. ${ }^{58}$ Congress left the task to the courts to fashion fame on their own. Courts narrowly construed niche fame against diluters of fame and limited the protection in cases where the diluters were using similar famous names in the very same niche. Over time, judicial recognition of broad protection for niche fame diminished as some courts have insisted that very few deserving trademarks can be deemed truly famous and are qualified for the expansive, national right against all diluters in all industries, markets and geographical regions. ${ }^{59}$

The last nail in the coffin for the "big fish in a small pond" theory for the protection of fame came in late 2006, when Congress passed the TDRA which eliminated niche fame and imposed a substantially higher degree of fame that a trademark must possess for the purpose of dilution law. ${ }^{60}$ The theory, however, is not completely dead, as courts continue

Dennison Corp., 189 F.3d at 875 ("[T]o meet the 'famousness' element of protection under the dilution statutes "“a mark [must] be truly prominent and renowned." (quoting I.P. Lund Trading ApS v. Kohler Co., 163 F.3d 27, 46 (1st Cir. 1998)).

54 Thane Int'l, 305 F.3d at 911.

55 TCPIP Holding Co., 244 F.3d at 99; Friesland Brands, B.V. v. Viet. Nat. Milk Co., 228 F. Supp. 2d 399, 412 (S.D.N.Y. 2002) ("Congress envisioned that marks would qualify as 'famous' only if they carried a substantial degree of fame." (citations omitted)).

56 Friesland Brands, B.V., 228 F. Supp. 2d at 412 (noting that examples of famous marks given in legislative reports were household words like "Buick" or "Kodak"); Eli Lilly \& Co. v. Natural Answers, Inc., 233 F.3d 456, 466 n.4 (7th Cir. 2000) (noting actions are available to protect famous trademark against diluters for using "DuPont shoes, Buick aspirin, . . . and Kodak pianos").

57 Thane Int'l, 305 F.3d at 911.

58 Componentone, L.L.C. v. Componentart, Inc., No. 02:05cv1122, 2007 WL 4302108, at*1 (W.D. Pa. Dec. 6, 2007) ("Prior to the amendment, the statute contained no language defining fame so specifically or narrowly.").

59 See, e.g., Thane Int'l, 305 F.3d at 911; TCPIP Holding, 244 F.3d at 99; I.P. Lund Trading, 163 F.3d at 46.

60 See Milbank Tweed Hadley \& McCloy LLP v. Milbank Holding Corp., 82 U.S.P.Q.2d 1583, 1588 (C.D. Cal. 2007) (stating that the TDRA precludes a finding of niche market fame); Dan-Foam A/S v. Brand Named Beds, LLC, 500 F. Supp. 2d 296, 307 n.90 (S.D.N.Y. 2007) (stating that the inclusion of the phrase "widely recognized by the general consuming public in the United States" in the TDRA rejected dilution claims based on niche market factors). 
to misread the revised statute and bestow famous status on trademarks known only in niche markets. ${ }^{61}$

\section{PRotecting FAme Beyond the Niche}

\section{A. Fame-Widely Recognized by the General Consuming Public}

On October 6, 2006, Congress revamped the law on fame by amending the trademark anti-dilution statute. Under the TDRA, the level of fame required is a much higher burden for a trademark holder to prove. ${ }^{62}$ The holder must establish that its trademark is "widely recognized by the general consuming public of the United States." 63 Trademarks with a level of fame recognized by the public only in a specialized segment or geographic place or region in the United States are not protected..$^{64}$

Also, by limiting the general consuming public to the United States, the TDRA adheres to the territoriality of trademark law. ${ }^{65}$ The

61 See infra Part IV.

62 The TDRA prescribes that:

(c) Dilution by blurring; dilution by tarnishment

(1) Injunctive relief

Subject to the principles of equity, the owner of a famous mark that is distinctive, inherently or through acquired distinctiveness, shall be entitled to an injunction against another person who, at any time after the owner's mark has become famous, commences use of a mark or trade name in commerce that is likely to cause dilution by blurring or dilution by tarnishment of the famous mark, regardless of the presence or absence of actual or likely confusion, of competition, or of actual economic injury.

(2) Definitions

(A) For purposes of paragraph (1), a mark is famous if it is widely recognized by the general consuming public of the United States as a designation of source of the goods or services of the mark's owner. In determining whether a mark possesses the requisite degree of recognition, the court may consider all relevant factors, including the following:

(i) The duration, extent, and geographic reach of advertising and publicity of the mark, whether advertised or publicized by the owner or third parties.

(ii) The amount, volume, and geographic extent of sales of goods or services offered under the mark.

(iii) The extent of actual recognition of the mark.

(iv) Whether the mark was registered under the Act of March 3, 1881, or the Act of February 20, 1905, or on the principal register.

15 U.S.C. § 1125(c) (2006).

63 Id. (providing the definition of "famous" mark).

64 See Roederer v. J. Garcia Carrión, S.A., 732 F. Supp. 2d 836, 879 (D. Minn. 2010) (“A mark that is famous only within a niche market does not qualify as 'famous' within the meaning of [the TDRA's] § 1125(c).”).

65 Fuji Photo Film Co. v. Shinohara Shoji Kabushiki Kaisha, 754 F.2d 591, 599 (5th Cir. 1985) (explaining that trademark territoriality is "basic to trademark law," in large part because 
fame of a trademark is confined within its national territory. ${ }^{66}$ That means evidence demonstrating that a particular mark is widely recognized by the general consuming public in other countries is not considered part of or a substitution for fame recognition by the U.S. general consuming public. ${ }^{67}$

In determining whether a mark has achieved fame or "possesses the requisite degree of recognition," the TDRA permits courts to consider "all relevant factors, including" four specific factors identified in the statute: (i) the duration, extent, and geographic reach of advertising and publicity of the trademark; (ii) the amount, volume, and geographic extent of sales of goods or services offered under the mark; (iii) the extent of actual recognition of the mark; and (iv) whether the mark was registered on the Principal Register with the Trademark Office. ${ }^{6}$

The first and second factors reflect the traditional concepts of marketplace recognition that courts have applied for decades in evaluating and determining fame in general. ${ }^{69}$ The third factor, "the extent of actual

"trademark rights exist in each country solely according to that country's statutory scheme"); Am. Foods, Inc. v. Golden Flake, Inc., 312 F.2d 619, 625 (5th Cir. 1963) (stating that trademark protection is territorial and the protection is limited to the areas in which the mark has been used).

66 Person's Co. v. Christman, 900 F.2d 1565 (Fed. Cir. 1990) (finding the Japanese trademark "Person," though known in Japan, has no reputation in the United States, meaning the known foreign mark has no priority in the United States); see also Grupo Gigante SA De CV v. Dallo \& Co., 391 F.3d 1088, 1093 (9th Cir. 2004) ("The territoriality principle, as stated in a treatise, says that '[p]riority of trademark rights in the United States depends solely upon priority of use in the United States, not on priority of use anywhere in the world."').

67 See generally Person's Co., 900 F.2d 1565.

68 See 15 U.S.C. $\$ 1125(c)(2)$; see also Roederer, 732 F. Supp. 2d at 879 ("In determining whether a mark is famous, a court may consider all relevant factors, including (1) the duration, extent, and geographic reach of advertising and publicity of the mark, whether advertised or publicized by the owner or third parties, (2) the amount, volume, and geographic extent of sales of goods offered under the mark, (3) the extent of actual recognition of the mark, and (4) whether the mark was registered under the Act of March 3, 1881, or the Act of February 20, 1905, or on the Principal Register.").

69 See Gen. Motors Co. v. Urban Gorilla, LLC, No. 2:06-CV-00133 BSJ, 2010 WL 5395065, at *5 (D. Utah Dec. 27, 2010) ("The company has spent hundreds of millions of dollars advertising Hummer products in print, on television, online, at the point of sale, and at events. Promotion of the brand has been world-wide. Many of the Hummer marks are licensed to other companies for non-automotive products such as golf carts and toys. These licensed products results in over \$2 billion in revenue to GM annually."); Visa Int'1 Serv. Ass'n v. JSL Corp., 590 F. Supp. 2d 1306 (D. Nev. 2008) ("IIn applying the first factor of the TDRA, the court finds that the plaintiff] has widely promoted and advertised the VISA mark for more than twenty-five years in print, on the internet, and in other media. During the four-year period from 1997 through 2000, Plaintiff spent more than $\$ 1$ billion on advertising in the United States. With regard to geographical reach, the VISA mark has been used in each of the fifty states, in more than 300 countries and territories, and on the internet. Given this evidence, the court concludes that this factor weighs strongly in favor of a finding that VISA is a famous mark" (citations omitted).). With respect to the second factor, the court in General Motors Co. found that the plaintiff showed that its sales were $\$ 2$ billion in annual revenue. 2010 WL 5395065, at $* 5$.

Prior to the passage of the TDRA, the court in AM General Corp. v. DaimlerChrysler Corp. considered whether a group of marks owned by Chrysler-Daimler were famous as follows:

In deciding whether DaimlerChrysler's family of marks is "famous" within the 
recognition of the mark," is meant to incorporate survey evidence, market research such as brand-awareness studies, unsolicited media coverage, as well as other evidence of consumer recognition of the mark. ${ }^{70}$ The last factor is registration of the trademark. This factor does not have any probative value in evaluating fame, as the mere existence of a registration really is not relevant to whether a trademark is famous. ${ }^{71}$ The phrase, "all relevant factors, including" suggests that the factors are nonexclusive, and courts therefore have discretion to consider factors outside the four named factors. ${ }^{72}$

Upon establishing the requisite fame, the trademark owner will then proceed to the next step of proving dilution under either the blurring theory ${ }^{73}$ or tarnishment theory. ${ }^{74}$ Conversely, without the requisite fame, the trademark holder fails to attain the antidilution protection claim for its mark. If the trademark owner prevails on both fame identity and one of the dilution theories, remedies such as injunction and damages may be available. ${ }^{75}$

meaning of the statute, the court is to consider the family's inherent distinctiveness or secondary meaning, the time and extent of DaimlerChrysler's use of the family in connection with motor vehicles, the duration and extent of DaimlerChrysler's advertising and publicity of the family, the size of the trading area in which DaimlerChrysler uses the family of marks, the channels of trade for motor vehicles, the degree of recognition of the family in those trading areas and channels of trade, whether and how others use similar marks, and whether the family is registered. 311 F.3d 796, 804 (7th Cir. 2002).

70 See Gen. Motors, 2010 WL 5395065, at *5 (finding that plaintiff General Motors met the third factor of the TDRA because "the survey results suggest high levels of actual recognition of the Hummer marks. Over $71 \%$ of participants were able to produce the names GM or Hummer when shown an image of a boxy, military-style vehicle. Thus, consumers know these marks by look and name").

71 Roederer, 732 F. Supp. 2d at 880 (finding that the mark in question for anti-dilution protection was registered and noting that "one cannot logically infer fame from the fact that a mark is one of the millions on the federal Register" (citation omitted)).

72 See Visa Int'l Serv. Ass'n, 590 F. Supp. 2d at 1315 (noting the "fame" factors are "nonexclusive").

73 See 15 U.S.C. $\S 1125(\mathrm{c})(2)(\mathrm{B})$ (2006) (defining "dilution by blurring" as "association arising from the similarity between a mark or trade name and a famous mark that impairs the distinctiveness of the famous mark"). In determining whether a mark or trade name is likely to cause dilution by blurring, the court may consider all relevant factors, including the following:

(i) The degree of similarity between the mark or trade name and the famous mark.

(ii) The degree of inherent or acquired distinctiveness of the famous mark.

(iii) The extent to which the owner of the famous mark is engaging in substantially exclusive use of the mark.

(iv) The degree of recognition of the famous mark.

(v) Whether the user of the mark or trade name intended to create an association with the famous mark.

(vi) Any actual association between the mark or trade name and the famous mark. Id.

74 See id. $\S 1125(c)(2)(C)$ (defining "dilution by tarnishment" as "association arising from the similarity between a mark or trade name and a famous mark that harms the reputation of the famous mark").

75 The remedies available under the statute include injunctive relief under $\S 1116$ and 


\section{B. Old Fame versus New Fame}

The new fame factors in the TDRA, hailed as "more narrowly focused" on identifying famous trademarks, ${ }^{76}$ replace the longer list of nonexclusive factors in the old statute. Under the old statute, the factors for proving fame are as follows:

\section{(A) the degree of inherent or acquired distinctiveness of the mark;}

additional remedies such as profits, damages, and costs and attorney fees under $\S 1117$ (a), if the violation is willful. See id. $\$ 1125(c)(1) \&(5)$. Additional remedies are provided in relevant paragraphs:

In an action brought under this subsection, the owner of the famous mark shall be entitled to injunctive relief as set forth in section 1116 of this title. The owner of the famous mark shall also be entitled to the remedies set forth in sections 1117(a) and 1118 of this title, subject to the discretion of the court and the principles of equity if-

(A) the mark or trade name that is likely to cause dilution by blurring or dilution by tarnishment was first used in commerce by the person against whom the injunction is sought after October 6, 2006; and

(B) in a claim arising under this subsection-

(i) by reason of dilution by blurring, the person against whom the injunction is sought willfully intended to trade on the recognition of the famous mark; or

(ii) by reason of dilution by tarnishment, the person against whom the injunction is sought willfully intended to harm the reputation of the famous mark.

\section{Id. $\S 1125(\mathrm{c})(5)$}

Remedies set forth in $\S 1117$ include:
(a) Profits; damages
costs; attorney
fees

When a violation of any right of the registrant of a mark registered in the Patent and Trademark Office, a violation under section 1125(a) or (d) of this title, or a willful violation under section 1125 (c) of this title, shall have been established in any civil action arising under this chapter, the plaintiff shall be entitled, subject to the provisions of sections 1111 and 1114 of this title, and subject to the principles of equity, to recover (1) defendant's profits, (2) any damages sustained by the plaintiff, and (3) the costs of the action. The court shall assess such profits and damages or cause the same to be assessed under its direction. In assessing profits the plaintiff shall be required to prove defendant's sales only; defendant must prove all elements of cost or deduction claimed. In assessing damages the court may enter judgment, according to the circumstances of the case, for any sum above the amount found as actual damages, not exceeding three times such amount. If the court shall find that the amount of the recovery based on profits is either inadequate or excessive the court may in its discretion enter judgment for such sum as the court shall find to be just, according to the circumstances of the case. Such sum in either of the above circumstances shall constitute compensation and not a penalty. The court in exceptional cases may award Id. $\S 1117$. reasonable attorney fees to the prevailing party.

76 Trademark Dilution Revision Act of 2005 Hearings Before the Subcomm. on Courts, the Internet, and Intellectual Property on the Comm. on the Judiciary House of Representatives, 109th Cong. 26 (2005) [hereinafter TDRA Hearings] (statement of Anne Gundelfinger, President of the Int'l Trademark Assoc.), available at http://commdocs.house.gov/committees/judiciary/ hju98924.000/hju98924_0.HTM\#FN28 ("H.R. 683 proposes that the existing fame factors be simplified and replaced with non-exclusive factors that are more narrowly focused on identifying marks that are "widely recognized by the general consuming public of the United States.'”). 
(B) the duration and extent of use of the mark in connection with the goods or services with which the mark is used;

(C) the duration and extent of advertising and publicity of the mark;

(D) the geographical extent of the trading area in which the mark is used;

(E) the channels of trade for the goods or services with which the mark is used;

(F) the degree of recognition of the mark in [the] trading areas and channels of trade used by the marks' owner and the person against whom the injunction is sought. ;

(G) the nature and extent of use of the same or similar marks by third parties; and

(H) whether the mark was registered under the Act of March 3, 1881, or the Act of February 20, 1905, or on the principal register. ${ }^{77}$

Comparing the above factors of the old statute to the factors for determining fame under the TDRA, there is a noticeable difference. The old fame factors have been simplified and combined into the new factors. A careful examination, however, reveals in reality that there is not much difference, as many of the factors in the old statute are similar to those of the new statute. For example, factor $(C)$ of the old statute is factor (i) of the new statute. Factors (B), (D), and (E) of the old statute are condensed into factor (ii) of the new statute. Factor $(\mathrm{F})$ is now replaced by the new factor (iii). Factor $(\mathrm{H})$ is the new factor (iv) ${ }^{78}$

The only factor in the old statute absent in the new one is Factor (A), inherent or acquired distinctiveness of the mark. This factor was excluded in response to the conflict among the federal appellate circuits as some required famous marks to possess "inherent distinctiveness" while others declined to impose such a requirement. ${ }^{79}$ Excluding the distinctiveness factor, the new statute extends anti-dilution protection to trademarks qualified as famous, regardless if they are inherently distinctive or have acquired a secondary meaning. ${ }^{80}$

77 Federal Trademark Dilution Act, Pub. L. No. 104-98, § 3(a), 109 Stat. 985 (1996).

78 See 15 U.S.C. $\S 1125$ (c) (2006).

79 H.R. REP. No. 109-23, at 5 (2005) ("Hearings revealed that the regional circuits interpret the FTDA differently on such matters as what constitutes a 'famous' mark, whether marks with 'acquired distinctiveness' are protected under the statute...."), available at http://www.gpo.gov/fdsys/pkg/CRPT-109hrpt23/pdf/CRPT-109hrpt23.pdf.

80 Under the old federal dilution statute, the trademark must be inherently distinctive. Acquired distinctiveness through secondary meaning was not enough. See Malletier v. Dooney \& Bourke, Inc., 561 F. Supp. 2d 368, 380 (S.D.N.Y. 2008) ("It is not enough for a trademark holder to show that the mark has acquired secondary meaning. Rather, the plaintiff must demonstrate that the mark is inherently distinctive to prevail [under the federal dilution statute]."); see also Times Mirror Magazines, Inc. v. Las Vegas Sports News, L.L.C., 212 F.3d 157, 164 (3d Cir. 
In the end, the most important difference between the two statutes with respect to famousness is how "famous" is defined or how "famous" a mark must be in order to be deemed as legally famous for antidilution protection. ${ }^{81}$ The niche fame embodied in actor $(\mathrm{F})$ of the old statute, that allowed any mark famous within a given trade or locale, ${ }^{82}$ but unknown to others outside the trade or region, has been replaced with a new stringent standard of famousness. ${ }^{83}$ The new statute emphasizes that a mark is famous if and only if it is "widely recognized by the general consuming public of the United States." 84 This begs the question of what constitutes the "general consuming public." The House Report accompanying H.R. 683 partially provides the answer that "the legislation expands the threshold of 'fame' and thereby denies protection for marks that are famous only in 'niche' markets." 85 That means the consuming public in a particular trade or geographical region does not constitute the general consuming public. The new legislation requires that the consuming public come from all different markets, sectors, and regions of the United States.

\section{StRUGGLING WITH FAME}

Applying the new standard of fame under the TDRA, courts have had difficulty in the last five years in the fame category. Some courts ignored the new law and applied the rejected old niche fame law. Some

2000) (stating that protection from dilution uses is available only to marks that are "highly distinctive"); Avery Dennison Corp. v. Sumpton, 189 F.3d 868, 876 (9th Cir. 1999) (noting that the then federal trademark dilution statute applies "only to those marks which are both truly distinctive and famous").

81 H.R. REP. NO. 109-023, at 8 ("Substantial portions of $\S 2$ are based on the existing FTDA, but there are conspicuous differences between the two texts. ... [H.R. 683] expands the threshold of 'fame' and thereby denies protection for marks that are famous only in 'niche' markets.").

82 Times Mirror Magazines, 212 F.3d at 174 (Barry, J., dissenting) (stating that "[i]f marks can be 'famous' within some market, depending on how narrowly that market is defined, then the FTDA will surely devour infringement law [and it is] hard to conceive of any consumer goods or services that are not in a narrow market of some type").

83 See Maker's Mark Distillery, Inc. v. Diageo N. Am., Inc., 703 F. Supp. 2d 671, 698 (W.D. Ky. 2010) (stating that niche mark is no longer recognized under the TDRA and finding that the plaintiff mark is not famous because the advertisement expenditure of \$22 million and annual sales of " 800,000 cases" does not indicate that the trademark is one of the nation's largest whisky producers).

84 TDRA Hearings, supra note 76 ("“T] a famous mark, namely a mark that is widely recognized by the general consuming public of the United States. This language narrows and strengthens the fame requirement. Dilution protection was never meant for the average trademark. It was intended to provide extraordinary protection for extraordinary marks.”).

85 H.R. REP. NO. 109-23, at 8 ("Substantial portions of $\S 2$ are based on the existing FTDA, but there are conspicuous differences between the two texts. ... [H.R. 683] expands the threshold of 'fame' and thereby denies protection for marks that are famous only in 'niche' markets."). 
courts abandoned the fame inquiry and leaped directly to the next inquiry; they focused on dilution by blurring or tarnishment inquiry. Other courts superficially engaged in the fame inquiry and rendered questionable conclusions on famous trademarks. The three types of cases are described and discussed more fully below.

\section{A. Still Applying the Old Niche Fame}

\section{Pet Silk, Inc. v. Jackson}

The plaintiff, Pet Silk, Inc., is a wholesaler of pet grooming products in connection with the trademark PET SILK within the fifteen years prior to the commencement of the litigation in 2007.86 In the trademark dilution suit, the district court found the trademark PET SILK famous under the TDRA. ${ }^{87}$

In that case, Pet Silk sold its products through a network of fifty distributors, both online and in pet supply retail stores. ${ }^{88}$ The defendants were a former distributor of Pet Silk products. Due to various businessrelated problems, the plaintiff decided to terminate its relationship with the defendants. ${ }^{89}$ However, after the termination the defendants continued to sell Pet Silk products, and implicitly held itself out as an authorized distributor of Pet Silk products. ${ }^{90}$ The plaintiff brought an antidilution claim along with a likelihood of confusion claim against the defendants. ${ }^{91}$ The plaintiff asserted, without any opposition from the defendant, that its trademark is famous in the pet supply and grooming market. ${ }^{92}$ The plaintiff moved for a preliminary injunction against the defendant. 93

In reaching its conclusion that PET SILK is a famous trademark, the court cited the trademark dilution law which mandates that the mark is famous "if it is widely recognized by the general consuming public of the United States as a designation of source of the goods or services of the mark's owner."94 Peculiarly, the court ignored the TDRA's widely recognized by the general consuming public requirement for finding a

86 Pet Silk, Inc. v. Jackson, 481 F. Supp. 2d 824 (S.D. Tex. 2007)

87 Id. at 830 .

88 Id. at $825-26$.

$89 \mathrm{Id}$. at 826.

90 Id. at $826-27$

$91 \mathrm{Id}$. at 828

92 Id. at 830 (noting that the plaintiff "testified" and that the defendant "does not contest, that Pet Silk ${ }^{\circledR}$ has name recognition in the pet supply and dog grooming market").

93 Id. at 834 (ordering the preliminary injunction against the defendant).

$94 \mathrm{Id}$. at $830 \mathrm{n} .8$ (quoting the statutory language for finding famous trademark and the factors for evaluating whether a mark is famous). 
mark famous, and relied on the Fifth Circuit's interpretation of the old trademark law identifying fame within a particular market. ${ }^{95}$ Summarily, the court found that "Pet Silk® has name recognition in the pet supply and dog grooming market." 96 In other words, the court continued to apply the old niche fame law squarely rejected by Congress under the TDRA. ${ }^{97}$

\section{Harris Research, Inc. v. Lydon}

The plaintiff, Harris Research, Inc., manufactures and distributes carpet cleaning equipment in conjunction with the trademark CHEMDRY to customers in the United States. ${ }^{98}$ The plaintiff has a network of 4000 franchises in 2600 locations throughout the United States. ${ }^{99}$ The defendants offered to sell and distribute shirts and stickers containing a "Chem-Who?" logo at an industry trade show. ${ }^{100}$ The plaintiff brought a trademark dilution claim, in addition to other claims, against the defendant. ${ }^{101}$ At the preliminary injunction proceeding, the court held in the plaintiff's favor, enjoining the defendant from using the "ChemWho?" logo. ${ }^{102}$

On the dilution claim, the court cited the TDRA for its new standard for fame, ${ }^{103}$ and yet concluded that the CHEM-DRY trademark possessed sufficient fame for anti-dilution protection. The court found the CHEM-DRY mark famous because it had been registered since 1979, used in advertisements throughout the United States, and sold through thousands of franchises. ${ }^{104}$ Also, to support the fame finding, the court relied on an assisted brand-awareness study which found the CHEMDRY mark is only known in the carpet cleaning industry. ${ }^{105}$ The court

95 Id. at 830 (stating that "the Fifth Circuit has held that market fame is sufficient" (citing Advantage Rent-A-Car, Inc. v. Enterprise Rent-A-Car, Co., 238 F.3d 378, 380 (5th Cir. 2001))).

96 Id. (noting the defendant did not object to the finding that the PET SILK is famous, even though it is only known within its niche).

97 Id. at 832 ("Under the new definition of dilution, the court finds that [Pet Silk] has presented enough evidence that it has a likelihood of success on its federal dilution claim.").

98 Harris Research, Inc. v. Lydon, 505 F. Supp. 2d 1161, 1164-65 (D. Utah 2007).

99 Id.

$100 \mathrm{Id}$.

101 Id.

102 Id. at 1169.

103 Id. at 1165 (stating that a "mark is famous if it is widely recognized by the general consuming public of the United States as a designation of source of the goods or services of the mark's owner").

$104 \mathrm{Id}$. at 1164 (recognizing that the plaintiff and its franchisees and licensees have spent " $\$ 22,000,000$ during 2006 in advertising and promoting the Chem-Dry brand and related products and services").

105 Id. at 1164 (noting that the aided awareness brand research in 2001 "of the Chem-Dry brand among current customers is $100 \%$, with total unaided awareness of the Chem-Dry brand 
wrongly equated the general public recognition to be "the general public in connection with carpet cleaning services."106

\section{B. Taking Fame for Granted-Leap to the Next Prong}

In the cases discussed below, courts ignored the fame requirement under the TDRA by not analyzing whether the marks in question are famous as required by statute. They intentionally forgot that, without the requisite fame, anti-dilution protection is simply not accorded. They instead took fame for granted by proceeding directly to the second inquiry regarding whether the defendant's use caused a likelihood of dilution. ${ }^{107}$

\section{Century 21 Real Estate LLC v. Century Insurance Group}

Century 21 Real Estate company brought a trademark infringement and dilution action against Century Insurance Group. ${ }^{108}$ The plaintiff asserted that its trademark CENTURY 21 is famous, and that the defendant's CENTURY trademark caused likelihood of dilution in violation of the federal statute. ${ }^{109}$

The court completely ignored the requisite requirement under the TDRA that the mark must be famous. ${ }^{110}$ Though the court acknowledged that the current trademark dilution law "revised" the old law, and that "protection is denied to marks that are famous in only 'niche' markets," the court did not engage in fame analysis. ${ }^{111}$ Instead, the court focused exclusively on whether the defendant's CENTURY mark is likely to cause dilution of the plaintiff's CENTURY 21 mark. ${ }^{112}$ The court examined whether the two marks are similar and found that they

\footnotetext{
being the highest in the industry").

$106 I d$. at 1166 ("Plaintiff has shown that the Trademark is widely recognized by the general public in connection with carpet cleaning services.").

107 See, e.g., Diane Von Furstenberg Studio v. Snyder, No. 1:06cv1356(JCC), 2007 WL 2688184 (E.D. Va. Sept. 10, 2007) (proceeding directly to likelihood of dilution instead and finding dilution against the defendant without first discussing whether the DVR trademark was "famous").

108 Century 21 Real Estate LLC v. Century Ins. Grp., No. CIV 03-0053-PHX-SMM, 2007 WL 484555, at*1 (D. Ariz. Feb. 8, 2007).

109 Id. at *14.

110 Id. at $* 14-15$

111 Id. at *14 ("[The TDRA] revised the Federal Trademark Dilution Act in three significant ways: (i) a likelihood of dilution, rather than actual dilution, is now required to establish dilution; (ii) courts may apply four factors to determine whether a mark is famous and protection is denied to marks that are famous in only 'niche' markets; and (iii) courts may apply six factors to determine whether a mark is likely to cause dilution by blurring.").

112 Id. at *16-18 (analyzing the factors for dilution by blurring).
} 
are not substantially similar to support a finding of likelihood of dilution. ${ }^{113}$ The court also analyzed the other factors of likelihood of dilution, and concluded that no reasonable jury would find for the plaintiff. ${ }^{114}$ Without engaging in fame analysis and making a finding as to whether the CENTURY 21 trademark is indeed famous as required by the TDRA, the court should not proceed with an extensive analysis of dilution by blurring, as the trademark is not qualified for protection under the statute.

\section{Autozone, Inc. v. Strick}

The plaintiffs in Autozone, Inc. v. Strick operate numerous automobile parts retail stores under the registered trademark AUTOZONE. ${ }^{115}$ The plaintiffs had also obtained a registration for its ZONE trademark in 2002 for retail automotive store services. ${ }^{116}$ On the other hand, the defendants known as Oil Zone, operate two locations in Illinois for a quick oil change business. ${ }^{117}$ One of the two locations also has a car wash operation that uses the mark WASH ZONE.118 The defendants obtained a trademark registration for OIL ZONE from the State of Illinois prior to the plaintiff using its ZONE trademark. ${ }^{119}$ The plaintiff brought an action of unfair competition, trademark infringement, and trademark dilution claims against the defendants. ${ }^{120}$

The court ruled in the defendants' favor on their motion for summary judgment which sought to dismiss all of the plaintiffs' claims. ${ }^{121}$ With respect to the federal dilution claim, the court noted that the TDRA is the governing law, and that it amended the federal antidilution statute by "favoring plaintiffs" with the likelihood of dilution standard. ${ }^{122}$ The court recognized that "the owner of a famous mark that is distinctive, inherently or through acquired distinctiveness, shall be

\footnotetext{
113 Id. at *15 (concluding "the differences between the C21 Marks and the Century Marks are so significant that consumers would not be confused by their contemporaneous registration and use").

114 See id. at *16-18 (applying the six factors listed in the TDRA for dilution by blurring).

115 Autozone, Inc. v. Strick, 466 F. Supp. 2d 1034 (N.D. Ill 2006), rev'd, 543 F.3d 923 (7th Cir. 2008).

116 Id. at 1036

117 Id.

$118 I d$.

119 Id. at 1036 (stating that OIL ZONE mark was registered by the defendant with the State of Illinois in 1996).

120 Id.

121 Id. at 1045 .

122 Id.
} 
entitled to an injunction" under the anti-dilution statute, if the owner can prove that the defendant's trademark was likely to cause dilution. ${ }^{123}$

The court, however, failed to address whether the plaintiffs' trademarks, AUTOZONE and ZONE, possess the heightened level of fame prerequisite for proving dilution under the TDRA. ${ }^{124}$ The court ignored whether the AUTOZONE and ZONE trademarks are recognized by the general consuming public in order to qualify for the anti-dilution protection. ${ }^{125}$ The court instead focused on the likelihood of dilution prong and dismissed the claim because the plaintiffs failed to submit evidence demonstrating the defendants' OIL ZONE and WASH ZONE marks were likely to cause dilution to the plaintiffs' marks, AUTO ZONE and ZONE. ${ }^{126}$

\section{Pan American World Airways, Inc. v. Flight 001, Inc.}

The plaintiff is the owner of the trademark PAN AM and Globe logo. ${ }^{127}$ It brought a trademark infringement and dilution action against the defendant for using the Globe logo. ${ }^{128}$ In a motion for a preliminary injunction, the district court summarily concluded that the Pan Am Globe trademark is famous and qualifies for protection under the TDRA. ${ }^{129}$

The plaintiff had purchased the PAN AM trademark through bankruptcy proceedings when the original Pan Am Company suffered financial crises and filed for bankruptcy in 1993. ${ }^{130}$ After the purchase, the plaintiff had modest airline operations under the trademark, but failed to succeed financially. ${ }^{131}$ The plaintiff then filed for bankruptcy and was acquired subsequently by a holding group in $1998 .{ }^{132}$ Consequently, the plaintiff narrowed the scope of its modest operations by offering limited flights within small geographical regions of the Northeast. ${ }^{133}$

\footnotetext{
123 Id. at $1044-45$.

124 Id. at 1045 (stating that under TDRA, plaintiffs only "bear the burden of showing at least a likelihood of dilution").

125 Id.

$126 I d$. (noting that "defendants have raised the issue of an inability to prove dilution, plaintiffs have made no attempt to show actual or likely dilution").

127 Pan Am. World Airways, Inc. v. Flight 001, Inc., No. 06 Civ. 14442(CSH), 2007 WL 2040588, at*1 (S.D.N.Y. July 13, 2007).

128 Id.

129 Id. at *19 (concluding that the plaintiff has "sufficiently established that the Pan Am Globe logo is famous").

130 Id. at *8.

131 Id. at $* 9$.

132 Id. at *9-10 (finding that the plaintiff's own bankruptcy filing had not caused the trademarks to be separated from the goodwill because there was not a "drastic alteration" in services that would cause the plaintiff to forfeit rights in the mark).

133 Id. at $* 10$.
} 
The defendant operates a chain of retail stores and a website that features travel-related products. ${ }^{134}$ The defendant did use the PAN AM trademark and logo in selling its products, but ceased after the plaintiff's attorney contacted the defendant. ${ }^{135}$ The defendant, however, continued to use the Flight 001 Globe logo.

In the trademark dilution claim, the court noted that the law had been recently amended. ${ }^{136}$ Under the new law, the TDRA, to "prevail on a claim of trademark dilution, plaintiff must show that its mark is 'famous." "137 However, the court failed to analyze whether the Pan Am Globe logo is famous as required by the TDRA. The court did not issue any finding on whether the Pan Am Globe logo is widely recognized by the general consuming public for protection under the TDRA. ${ }^{138}$ The court instead simply stated that the plaintiff "has sufficiently established that the Pan Am Globe logo is famous." 139 The court, not surprisingly, cited no evidence supporting its conclusion of fame. The court proceeded on whether the defendant's logo is likely to dilute the distinctiveness of the plaintiff's Pan Am Globe logo by applying the six factors listed in the statute for likelihood of dilution through blurring. ${ }^{140}$

\section{Questionable Findings for National Fame}

Some courts have relied on the correct legal standard under the TDRA for evaluating whether a trademark has the necessary fame for anti-dilution protection. A careful reading of the cases, however, reveals that although courts applied the factors propounded by the TDRA, they found the existence of national fame possessed by trademarks that are

134 Id. at $* 3$.

135 Id. at $* 3-4$.

136 Id. at *18 n.17 ("The quoted language is from a 2006 amendment to the statute. The amendment did away with the Supreme Court's holding in Moseley v. V Secret Catalogue, Inc. . . . that 'actual dilution must be established' in order to entitle a plaintiff to an injunction." (internal citation omitted)).

137 Id. at $* 18$.

138 Id. at *11 ("It is a famous logo that distinguishes Pan Am's goods and services from those of others. Furthermore, plaintiff's use of a light blue and white color scheme in combination with the PAN AM name, PAN AM mark and Pan Am Globe logo is likely to merit trade dress protection. Plaintiff has sufficiently established that, due to extensive usage and marketing, consumers associate this color and design scheme with Pan Am.").

139 Id. at *19.

140 Id. (explaining that the six factors include " "whether a mark or trade name is likely to cause dilution by blurring': (i) the degree of similarity between the mark or trade name and the famous mark; (ii) the degree of inherent or acquired distinctiveness of the famous mark; (iii) the extent to which the owner of the famous mark is engaging in substantially exclusive use of the mark; (iv) the degree of recognition of the famous mark; (v) whether the user of the mark or trade name intended to create an association with the famous mark; and (vi) any actual association between the mark or trade name and the famous mark" (citing 15 U.S.C. $§ 1125$ (c)(2)(B) (2006))). 
actually not known by the general consuming public across the United States. In other words, they erroneously bestowed national fame on niche variety trademarks.

\section{Dan-Foam A/S v. Brand Named Beds, LLC}

The plaintiff, Dan-Foam A/S, is a Danish corporation that manufactures premium foam-based mattresses, pillows, and cushions under the trademark TEMPUR-PEDIC. ${ }^{141}$ The plaintiff brought a dilution by tarnishment claim, among others, against the defendant for unauthorized sales of the Tempur-Pedic products. ${ }^{142}$ At summary judgment, the court denied the defendant's motion to dismiss the dilution claim. ${ }^{143}$

Dan-Foam's products are sold in the United States either through an authorized dealer network or Dan-Foam's licensees. ${ }^{144}$ The authorized dealer network includes physicians and other health care professionals, general bedding retailers, and specialty retailers such as Brookstone. ${ }^{145}$ The defendant, Brand Named Beds, LLC, was not an authorauthorized dealer for the plaintiff. ${ }^{146}$ The defendant sold viscoelastic foam bedding products, including Tempur-Pedic mattresses, over the Internet. ${ }^{147}$

The court concluded that a reasonable jury could find that the TEMPUR-PEDIC trademark is "widely recognized by the general consuming public of the United States as a designation of source of the goods ... of the mark's owner." 148 The court arrived at its conclusion even though it observed that the plaintiff merely "alleged" that the goodwill of the TEMPUR-PEDIC trademark had yielded tens of million

141 Dan-Foam A/S v. Brand Named Beds, LLC, 500 F. Supp. 2d 296, 297 (S.D.N.Y. 2007).

142 Id. at 298 .

143 Id. at 298 (denying the defendant's motion for summary judgment on all counts).

144 Id. at 300 (noting that Tempur-Pedic sold through the authorized dealers network come with warranty).

$145 I d$. at 301 (finding that the plaintiffs imposed a strict quality control on their products sold through the authorized dealers network).

146 Though Brand Named Beds, LLC, was not an authorized dealer, it obtained the TempurPedic products through Dan-Foam's authorized retailer. $I d$. at 302.

147 Brand Named Beds, LLC, had its own online retail store at www.brandnamebeds4less.com and sold products on eBay. Id.

148 Id. at 323 ("A consideration of the factors suggested by the TDRA could reasonably support a finding of famousness. The TEMPUR-PEDIC® trademark has been registered on the Principal Register of the United States Patent and Trademark Office since 1994. Since then, 'the duration, extent, and geographic reach of advertising and publicity of the mark' has been considerable. Tempur-Pedic advertises through newspaper and magazine ads, mailings, television commercials, infomercials, and on the internet. Tempur-Pedic 'actively' and 'continuously' advertises and promotes its products 'on a national level.' As a result, '[t]he brand is a highly regarded, distinctive, and widely known identifier of high quality, therapeutic mattresses, pillows, pads, cushions, slippers and other similar products."'). 
of sales. ${ }^{149}$ The court also stated that the plaintiff claimed that over the last three years, it spent in total an aggregate excess of $\$ 250$ million in connection with the advertisement and promotion of its products. ${ }^{150}$ Additionally, the plaintiff asserted that it had sold approximately 15,000 Tempur-Pedic mattresses for use at Veterans Administration facilities, general hospitals, rehabilitation and long-term care facilities, sleep centers, and labs. ${ }^{151}$ The plaintiff received recognition from Good Housekeeping and awards from Consumers Digest and the Arthritis Foundation for its beds. ${ }^{152}$

Peculiarly, the court reached its conclusion that the TEMPURPEDIC trademark is famous after it noted that the plaintiff had not offered any evidence regarding the "amount, volume, and geographic extent of sales of goods" offered under the TEMPUR-PEDIC trademark. ${ }^{153}$ The plaintiff presented no consumer survey to establish "actual recognition" of the TEMPUR-PEDIC trademark. ${ }^{154}$ The court then proceeded to the dilution prong and dismissed the defendant's motion for summary judgment on the dilution claim. ${ }^{155}$

\section{University of Kansas v. Sinks}

The University of Kansas and Kansas Athletics, Inc., a not-forprofit entity of the university created for the operation of intercollegiate athletic programs, brought an action against the defendants for manufacturing and selling trademarked products in violation of trademark dilution and infringement law. ${ }^{156}$ Specifically, the defendants used without authorization the plaintiff's trademarks KU with the crimson and blue scheme and the Jayhawk mascot. ${ }^{157}$

On the dilution claim, the jury found that the KU trademark is famous, and the defendants' use of the trademark was likely to cause dilution of the plaintiff's famous trademark and logo. ${ }^{158}$ The defendants

$149 I d$. (explaining that the plaintiff alleged that " "the goodwill associated with the TEMPURPEDIC $®$ trademark has translated into tens of millions of dollars in sales over the years,' and that '[i]n the past three years alone, sales of goods bearing the TEMPUR-PEDIC $®$ trademark have exceeded $\$ 2$ billion'”).

$150 I d$. at 323 n.209 (citing to the plaintiff's Complaint).

151 Id. at 323.

152 Id. ("Good Housekeeping magazine has 'recognized' Tempur-Pedic's mattresses, and Tempur-Pedic has 'received awards from Consumers Digest and the Arthritis Foundation."').

153 Id. ("The parties have not presented much evidence regarding ' $[\mathrm{t}]$ he amount, volume, and geographic extent of sales of goods ... offered' under the TEMPUR-PEDIC® mark.”).

154 Id. at 323-24.

155 Id. at 324-27.

156 Univ. of Kan. v. Sinks, 644 F. Supp. 2d 1287 (D. Kan. 2008).

157 Id. at $1305-06$.

158 Id. at $1293-94,1304$ (the jury returned the verdict on all counts against the defendants). 
moved for judgment as a matter of law to set aside the jury's verdict, since there was lack of evidence at trial to establish that the plaintiff's trademarks "enjoy widespread fame." 159 The court denied the defendants' post-trial motion and affirmed the jury's finding. ${ }^{160}$

The court found that there was "sufficient evidence of national fame" to satisfy the TDRA. ${ }^{161}$ For example, the court relied on the evidence of the use of the KU marks in non-sporting events, unsolicited media coverage of athletic teams, plus the use of trademarks by the plaintiff for over 100 years. ${ }^{162}$ The court concluded that the combination of evidence, including "advertising, unsolicited media references, brochures about the University, and substantial sales of KU's licensed merchandise displaying the marks" supports the jury's finding of "national fame" for the KU marks. ${ }^{163}$

The defendants argued that the KU trademark is known only in the collegiate sports niche. Specifically, the defendant compared the KU trademark to the UT (University of Texas) and longhorn logo marks, and asserted that the KU marks do not enjoy national widespread fame as required under the TDRA. ${ }^{164}$ The defendant buttressed its argument with a published decision on the UT and longhorn logo marks. Despite the fact that the UT and longhorn logo marks are known through regularly televised football games, extensive licensing programs, and appearances of the marks on Wheaties boxes, the district court in Texas held that the UT and longhorn logo marks do not possess the widespread fame required under the TDRA.165 Therefore, the defendant argued, the jury verdict on widespread national fame possessed by the KU marks should be overturned. The court in the KU trademark case, however, rejected the defendant's argument and conclusively found that, unlike the UT trademark, KU is not a niche-famous mark. ${ }^{166}$

159 Id. at 1306 ("[D] efendants argue that there was no evidence at trial that plaintiffs' marks enjoy widespread fame sufficient to support a finding of liability on the dilution claims.").

160 Id. at 1304 (denying defendants' motions for judgment as a matter of law and to alter or amend).

161 Id. at 1307.

162 Id. (finding that the plaintiffs "submitted an abundance of evidence on the use of the various marks both within and outside the context of sporting events. In addition to national media coverage and exposure of the athletic teams, plaintiff submitted evidence that KU has been referred to as 'Kansas' since the 1930s and that KU has used the crimson and blue color scheme and the Jayhawk mascot for over 100 years").

163 Id.

$164 I d$. at 1306-07 (noting that the defendants relied "entirely upon the analysis set forth in $B d$. of Regents, the University of Texas System v. KST Electric, Ltd.," 550 F. Supp. 2d 657, 679 (W.D. Tex. 2008), which addressed the "longhorn silhouette logo" and the court in that case "rejected the plaintiff's circumstantial evidence of fame because it all related to the use of the logo at or concerning sporting events").

165 Id.

166 Id. at 1307 (relying on testimony provided by KU to support the existence of a famous trademark). Specifically, the court noted that, "[w]hen viewed in the light most favorable to plaintiffs, this evidence, along with evidence of advertising, unsolicited media references, 


\section{New York City Triathlon, LLC v. NYC Triathlon Club, Inc.}

The plaintiff, the New York City Triathlon, LLC, owner of the trademark NEW YORK CITY TRIATHLON, brought a trademark dilution claim, among others, against the seller of triathlon equipment for using NYC TRIATHLON CLUB, NYC TRI CLUB, and NEW YORK CITY TRIATHLON CLUB. ${ }^{167}$ The court granted the plaintiff's motion for a preliminary injunction upon finding the trademark NEW YORK CITY TRIATHLON famous and that the defendant's use of the mark will likely cause dilution in violation of the TDRA. 168

The court, similar to other courts, provided the obligatory citations and quotations from the TDRA that a famous mark must be "widely recognized by the general consuming public of the United States,"169 and that there are four nonexclusive factors for courts to consider in determining fame. ${ }^{170}$ The court found the trademark NEW YORK CITY TRIATHLON famous under the TDRA, even though the plaintiff had only used it for about ten years, ${ }^{171}$ the plaintiff owned no federal registration for the trademark, ${ }^{172}$ its annual summer event attracted only about 20,000 potential triathlon athletes who vied for the 5600 entry spots, ${ }^{173}$ and the event raised about $\$ 2$ million each year for national charities. ${ }^{174}$ Despite these shortcomings, the court found that the trademark NEW YORK CITY TRIATHLON is "widely recognized" because national media outlets covered the plaintiff's event and companies

brochures about the University, and substantial sales of KU's licensed merchandise displaying the marks, supports the jury's finding of national fame. Likewise, defendants' evidence of third-party use of the marks does not require judgment in their favor as a matter of law. While the jury could certainly consider this evidence in making a determination of fame on the dilution claims, it was not required to weigh it more heavily than plaintiffs' evidence of fame. Under the standard this Court must apply on a motion for judgment as a matter of law, there was sufficient evidence upon which the jury could have found fame despite the evidence of third-party use." Id.

167 N.Y.C. Triathlon, LLC v. NYC Triathlon Club, Inc., 704 F. Supp. 2d 305, 311 (S.D.N.Y. 2010).

168 Id. at 327 ("Plaintiffs [sic] motion for an order preliminarily enjoining Defendant's ongoing trademark and trade name infringement, dilution, cybersquatting, unfair competition, and deceptive trade practices is granted.").

$169 I d$. at 321.

170 Id. (quoting 15 U.S.C. $\$ 1125(\mathrm{c})(2)(\mathrm{A})$ (2006) and the four factors from id. $\S 1125(\mathrm{c})(2)(\mathrm{A})(\mathrm{i})-(\mathrm{iv}))$.

171 Id. (stating that the NYC Triathlon is an Olympic distance triathlon, consisting of a 1500 meter swim in the Hudson River, a forty kilometer bike ride up the West Side Highway, and a ten kilometer run into Central Park which has been run every summer in New York City since 2001).

$172 I d$. (noting that the registrations for the plaintiff's trademarks are still pending).

173 Id . at 322 (observing that the plaintiff's annual summer triathlon event "sells out in minutes, with 20,000 people around the world this year vying for the 5,600 entry spots").

174 Id. ("Approximately $\$ 2$ million is raised each year for national charities, such as the American Cancer Society and the Leukemia \& Lymphoma Society."). 
such as Ford, Nautica, Gatorade, Visa, Dasani, JetBlue, among others, sponsored its event. ${ }^{175}$

\section{Dallas Cowboys Football Club, Ltd. v. America's Team Properties, Inc.}

The plaintiff, the Dallas Cowboys Football Club, the owner of an unregistered trademark AMERICA'S TEAM, brought a trademark action against the defendant. ${ }^{176}$ With respect to the trademark dilution claim, the court found that AMERICA'S TEAM qualified as a famous trademark for protection under the TDRA. ${ }^{177}$

The defendant obtained a federal registration for the trademark AMERICA'S TEAM in 1998, but first used it in commerce in 1990.178 The defendant used the trademark on t-shirts and sold them at sporting events. ${ }^{179}$ On the other hand, the plaintiff began using America's Team as the title of their football team's 1978 season highlight film. ${ }^{180}$ The plaintiff then used the term for a calendar in 1979-1980, sold a videocassette titled America's Team: The Dallas Cowboys 1975-1979, and granted a license to an entity for silver coins using the engraved term. ${ }^{181}$ The plaintiff also used the term on various souvenir products. In 1992, the plaintiff obtained a Texas trademark registration for DALLAS COWBOYS AMERICA'S TEAM for use on clothing. ${ }^{182}$ The plaintiff made "millions" selling items with the term at various locations in Texas and on the Internet. ${ }^{183}$

Similar to other courts who had bestowed national fame status on marks with limited recognition, the court in this case cited to the TDRA, and acknowledged that federal law imposes a "higher standard" for fame and requires that a mark is famous "if it is widely recognized by the general consuming public of the United States." 184 The court also reiterated the relevant factors for finding fame under the TDRA, such as

\footnotetext{
175 Id. ("It is clear that Plaintiff's marks are widely recognized.").

176 Dall. Cowboys Football Club, Ltd. v. Am.'s Team Props., Inc., 616 F. Supp. 2d 622 (N.D. Tex. 2009).

177 Id. at 643 .

178 Id. at $629-30$.

179 Id. at 630. In 2003, the defendant approached the plaintiff for the purchase and sale of the federal trademark registration. The plaintiff refused and brought the lawsuit against the defendant.

180 Id. at 631.

181 Id.

$182 I d$.

$183 \mathrm{Id}$.

184 Id. at 643 ("Federal law requires a higher standard, requiring a mark to be 'famous' as well as distinctive. "[A] mark is famous if it is widely recognized by the general consuming public of the United States as a designation of source of the goods or services of the mark's owner." (citing 15 U.S.C. § 1125(c)(1) (2006) and quoting $i d$. § 1125(c)(2)(A))).
} 
"the duration, extent, and geographic reach of advertising and publicity of the mark; the amount, volume, and geographic extent of sales of goods or services offered under the mark; the extent of actual recognition of the mark; and whether the mark was registered." 185 After the obligatory citation and quotation taken from the TDRA, the court summarily found that the plaintiff had "established the long duration and geographic reach" of the AMERICA'S TEAM trademark. ${ }^{186}$ Furthermore, with respect to the plaintiff's survey for "actual recognition" of the trademark, the court found that the plaintiff's survey "demonstrates actual recognition among a relevant consumer base." 187 The court failed to realize that the law requires wide recognition by the general consuming public, not the relevant consumer base of the plaintiff. The court concluded that AMERICA'S TEAM is famous, and proceeded with a positive finding of dilution by blurring and tarnishment against the defendant. 188

In summary, the cases above demonstrate that courts across the United States, five years after the TDRA became effective, are still having difficulty with the fame analysis. Some courts applied outright the legal standard that is no longer the law. Other courts cited the new statute, quoted the correct standard and factors, and yet engaged in a cursory analysis that rendered questionable findings of fame. Some courts ignored fame completely and advanced to the next inquiry under the TDRA by analyzing dilution by blurring or tarnishment to reach their intended results. These decisions are not acceptable; they are contrary to the requirement of a heightened level of fame under the TDRA. It is time to identify what has caused the courts to render such erroneous or questionable decisions, and to suggest changes for a more uniform result consistent with the intent of the TDRA.

\section{Defining FAME AS NATiOnal FAME}

The erroneous decisions rendered by district courts across the United States have several possible explanations. With respect to the cases wherein courts applied the wrong legal standard, courts will soon realize that the TDRA is the current law. This type of problem is not a major surprise, as the decisions were entered when the TDRA was still new on the book. It will disappear on its own as more recent cases consistently apply current law. ${ }^{189}$

185 Id.

186 Id.

187 Id. (emphasis added).

$188 I d$. (finding dilution under both federal and state statutes).

189 See, e.g., N.Y.C. Triathlon, LLC v. NYC Triathlon Club, Inc., 704 F. Supp. 2d 305, 321 
For the cases where courts ignored fame and proceeded to the dilution prong, there is a possible explanation. Fame is the threshold issue in a trademark dilution claim, and that means courts have no authority to ignore it. ${ }^{190}$ A possible explanation for judicial decisions to ignore the fame analysis is that the defendants in these cases either conceded too soon that the plaintiff's trademark is famous or failed to challenge that the plaintiff's trademark does not possess the high level of fame required by the TDRA that states it must be widely recognized by the consuming public of the United States. To rectify this situation demands an understanding of what "widely recognized by the general consuming public" really means. A solution to this problem will be discussed later below.

With regard to the cases where courts knew that the TDRA is the law, cited to the statute, extracted language from the TDRA for the high standard of fame, and reiterated the relevant factors listed in the TDRA for fame analysis, the problem is more acute. It seems that sentimentality and provincialism dictated the outcome. For example, the district court in Kansas held that the trademark KU and its mascot were famous under the TDRA, even though the marks were known only in the collegiate sports arena. ${ }^{191}$ Likewise, the district court of the Northern District of Texas where the Dallas Cowboys is located found that the plaintiff's AMERICA'S TEAM trademark is famous under the stringent fame standard. ${ }^{192}$ The court in the Southern District of New York ruled in favor of the plaintiff who organized the annual summer triathlon event under the term NEW YORK CITY TRIATHLON by finding the term famous according to the TDRA. ${ }^{193}$ Additionally, in these types of cases, the defendants did not always rigorously challenge the fame finding. These decisions made a mockery of the intention of the statute.

Courts are mandated to follow the language of the TDRA, as passed by Congress and effective since 2006. Courts must recognize that protection provided under the TDRA is reserved for only a very few worthy trademarks in the United States. Indeed, Congress only wanted anti-dilution protection for a very few deserving trademarks. ${ }^{194}$

(S.D.N.Y. 2010) (citing the TDRA); Dall. Cowboys Football Club, 616 F. Supp. 2d at 643 (citing the TDRA); Univ. of Kan. v. Sinks, 644 F. Supp. 2d 1287, 1306 (D. Kan. 2008) (citing the TDRA).

190 See Maker's Mark Distillery, Inc. v. Diageo N. Am., Inc., 703 F. Supp. 2d 671, 697-98 (W.D. Ky. 2010) ("Whether a mark is 'famous' is the threshold issue in a trademark dilution claim. 'Fame' is a lexicon of art particular to trademark jurisprudence; it is not at all the same as asking 'the man on the street' whether a name, mark or product is 'famous.' It is not proven through the words of trade publication articles declaring it so.").

191 Univ. of Kan., 644 F. Supp. 2d 1287.

192 Dall. Cowboys Football Club, 616 F. Supp. 2d 622.

193 N.Y.C. Triathlon, 704 F. Supp. 2d 305.

194 Anti-dilution protection for famous marks means "a limited group of marks that are genuinely famous." TDRA Hearings, supra note 75, at 10; see also H.R. REP. NO. 109-23, at 8 
The rationale rested on the recognition that whereas an ordinary trademark's infringement action requires proof of likelihood of consumer confusion, ${ }^{195}$ a famous trademark qualified for anti-dilution protection has the power to block uses of a similar or identical mark on goods or services that are not actually competing, ${ }^{196}$ and there is therefore an absence of likelihood of consumer confusion originating from the use of the junior trademark in the marketplace. ${ }^{197}$ In other words, famous trademarks are viewed as property, just like patents and copyrights, and the holders of such marks enjoy the property-like protection to preserve their investment in the marks under the anti-dilution law. ${ }^{198}$ That means

(2005) ("In addition, the [TDRA] expands the threshold of 'fame' and thereby denies protection for marks that are famous only in 'niche' markets."); Duvall, supra note 28, at 1262 ("The TDRA's revised fame standard will help keep dilution law in check and should resolve the concerns of most critics that the FTDA was too often applied in cases where it was not justified.").

195 See 15 U.S.C. $§ 1125$ (a) (2006):

(1) Any person who, on or in connection with any goods or services, or any container for goods, uses in commerce any word, term, name, symbol, or device, or any combination thereof, or any false designation of origin, false or misleading description of fact, or false or misleading representation of fact, which-

(A) is likely to cause confusion, or to cause mistake, or to deceive as to the affiliation, connection, or association of such person with another person, or as to the origin, sponsorship, or approval of his or her goods, services, or commercial activities by another person, or

(B) in commercial advertising or promotion, misrepresents the nature, characteristics, qualities, or geographic origin of his or her or another person's goods, services, or commercial activities,

shall be liable in a civil action by any person who believes that he or she is or is likely to be damaged by such act.

196 Scott Fetzer Co. v. House of Vacuums Inc., 381 F.3d 477, 489 (5th Cir. 2004) (noting that dilution of a famous trademark through blurring "involves a diminution in the uniqueness or individuality of a mark because of its use on unrelated goods"). The idea of broad protection for famous trademarks has long been advocated by the courts. See Commc'ns Satellite Corp. v. Comcet, Inc., 429 F.2d 1245, 1248 (4th Cir. 1970) ("COMSAT has become recognized throughout the United States as identifying and distinguishing plaintiff and its communications services. These facts ... establish it as a strong mark and a famous name.... [I]t is entitled to broad protection.”); Hanson v. Triangle Publ'ns, 163 F.2d 74, 76 (8th Cir. 1947) (affirming the district court's finding that the defendant's use of the trademark SEVENTEEN on dresses was for the purpose of trading on taking "unfair advantage of the [Seventeen] magazine's fame, reputation and good will”); Holiday Inns, Inc. v. Holiday Inn, 364 F. Supp. 775, 783 (D.S.C. 1973) ("The plaintiff's marks are famous throughout the United States and are becoming well known in many other countries. ... These property rights of the plaintiff are entitled to broad protection."); Stix Prods., Inc. v. United Merchs. \& Mfrs., 295 F. Supp. 479, 483 (S.D.N.Y. 1968) ("By 1958 United's products under its trade-mark CON-TACT had gained commercial acceptance, and the name was recognized by the industry and the purchasing public as a Famous Brand.").

197 See 15 U.S.C. $\$ 1125$ (c)(1) (2006) ("[T]he owner of a famous mark that is distinctive, inherently or through acquired distinctiveness, shall be entitled to an injunction against another person who, at any time after the owner's mark has become famous, commences use of a mark or trade name in commerce that is likely to cause dilution by blurring or dilution by tarnishment of the famous mark, regardless of the presence or absence of actual or likely confusion, of competition, or of actual economic injury.").

198 See Kellogg Co. v. Toucan Golf, Inc., 337 F.3d 616, 628 (6th Cir. 2003) (stating that dilution law, unlike trademark infringement, is not based on a likelihood of confusion standard, 
only trademarks that are "widely recognized by the general consuming public of the United States" are accorded property-like power. 199 Trademarks with this fame status are and should be very scarce. Courts must follow the statute and function as gatekeeper of the fame portal, so only very few trademarks can pass through for the heightened protection propounded under the trademark jurisprudence.

To adhere to the language and the intent of the statute, courts must equate the phrase, "widely recognized by the general consuming public of the United States," to mean that the mark must have national fame.200 A mark with national prominence such as the University of Texas (UT) trademark and its longhorn silhouette logo are not marks with national fame, as prominent marks are known only within a particular niche, such as, collegiate sports, although the niche is nationwide. ${ }^{201}$ Marks

\footnotetext{
"but only exists to protect the quasi-property rights a holder has in maintaining the integrity and distinctiveness of his mark"); see also Dan L. Burk \& Brett H. McDonnell, Trademarks and the Boundaries of the Firm, 51 WM. \& MARY L. REV. 345, 353 (2009) ("Treatment of trademarks as independent property is also apparent in claims for dilution. Dilution recognizes that the value of certain famous marks will be diminished if they are used too often in the marketplace; unauthorized but nonconfusing uses can be restricted by the mark owner in order to preserve the mark's distinctiveness."); Jonathan Moskin, Victoria's Big Secret: Whither Dilution Under the Federal Dilution Act?, 93 TRADEMARK REP. 842, 843-44 (2004) ("[T]wentieth century trademark law... witnessed the expansion of trademark rights from a tort-based theory preventing direct diversion of sales between competitors to a broader set of rights resting on a recognition that trademarks themselves possess economic value ....”); Simone Rose, Will Atlas Shrug? Dilution Protection for "Famous" Trademarks: Anti-Competitive "Monopoly" or "Earned" Trademark Right?, 47 FLA. L. REV. 653, 740 (1995) ("[V]iewing dilution relief as protecting an earned property interest should help engender a positive presumption that dilution protection effectively protects the source identification, persona and quality assurance property of famous and 'highly distinctive 'trademarks. Dilution statutes would finally mirror traditional trademark, patent and copyright statutes by providing the most effective balance between rewarding the creator of famous marks while simultaneously promoting free market competition and the free dissemination of ideas. Atlas will no longer shrug, but welcome the addition of these earned property rights."); Wilf, supra note 47 ("Dilution doctrine represented a shift from a tort model to a proprietary model of trademark. Trademarks had been transformed into a distinct form of property with uncanny psychological power.").

199 Commentators have also observed that the protection for famous trademarks under TDRA is so broad, "it provides strong incentives for wealthy companies to strive to make each mark "widely recognized by the general consuming public of the United States." Alexandra J. Roberts, New-School Trademark Dilution: Famous Among the Juvenile Consuming Public, 49 IDEA 579, 645 (2009).

200 Oriental Fin. Grp. v. Cooperativa De Ahorro y Crédito Oriental, No. 10-1444 (JAF), 2010 WL 4117236 (D.P.R. 2010) (finding that the plaintiff failed to prove that the trademark ORIENTAL has achieved "national fame" as required under federal dilution law); Nat'l Bus. Forms \& Printing, Inc. v. Ford Motor Co., No. H-08-1906, 2009 WL 3570387, at *7 n.18 (S.D. Tex. Oct. 30, 2009) ("If Ford intends to pursue dilution claims regarding these products at trial, it must proffer evidence showing that each mark it alleges was diluted has achieved the requisite degree of 'national fame' necessary to support a trademark dilution claim.").

201 See Bd. of Regents, Univ. of Tex. Sys. v. KST Elec., Ltd., 550 F. Supp. 2d 657, 678 (W.D. Tex. 2008) ("Simply because UT athletics have achieved a level of national prominence does not necessarily mean that the longhorn logo is so ubiquitous and well-known to stand toe-to-toe with Buick or KODAK.").
} 
with national prominence like UT and KU are not necessarily marks that have become household names throughout the United States. ${ }^{202}$

That means the courts should impose upon the plaintiff the burden of submitting a consumer survey evidencing the overall, general consuming public recognition of the trademark throughout the United States. ${ }^{203}$ Obviously, the survey must be conducted according to accepted principles. ${ }^{204} \mathrm{~A}$ well-designed, properly-conducted survey is reliable direct evidence of whether the mark is indeed recognized by the public. ${ }^{205}$

Complying with the TDRA, the survey samples cannot concentrate on the consuming public within a particular population, industry, or market. ${ }^{206}$ Also, the survey samples must be taken from many locations across the United States to reflect the overall general consuming public recognition of the trademark at issue. ${ }^{207}$ The recognition level must be at least seventy percent of the overall general consuming public of the United States, identifying the trademark as a source identifier of only the plaintiff's goods or services. ${ }^{208}$

202 See Thane Int'l, Inc. v. Trek Bicycle Corp., 305 F.3d 894, 911 (9th Cir. 2002) (holding that dilution protection extends only to those whose mark is a "household name").

203 Under the old dilution statute, courts criticized plaintiffs for not conducting consumer survey evidence to prove fame. See TCPIP Holding Co., v. Haar Commc'ns, Inc., 244 F.3d 88, 99-100 (2d Cir. 2001) (finding that the plaintiff's evidence of sales and advertising expenditures failed to establish fame and noting that the plaintiffs had offered no consumer recognition survey to support its alleged fame).

204 Prudential Ins. Co. of Am. v. Gibraltar Fin. Corp. of Cal., 694 F.2d 1150, 1156 (9th Cir. 1982) (finding that the district court erred in excluding trademark survey evidence that showed the percentage of the public identified Prudential's Gibraltar logo as a source of its insurance services).

205 See Alan S. Cooper, How the Courts are Applying the Federal Trademark Dilution Act as Amended by the Trademark Dilution Revision Act of 2006, SN053 ALI-ABA 247, 255 (2009) (suggesting that "[d]irect evidence in the form of a properly designed and conducted survey that establishes such national public recognition would seem to carry far greater weight than circumstantial evidence").

206 Hal Poret, Hot Topics in Trademark Surveys, 968 PLI/Pat 133, 143 (2009) (asserting that "researchers attempting to measure dilution should think carefully before: (1) using a universe that is defined so as to be limited to a specialized class of consumers; and (2) limiting the universe to a particular geography. Such definitions of the universe may be criticized and possibly lead to the exclusion of the survey").

207 Id.

208 See 7-Eleven Inc. v. Wechsler, 83 U.S.P.Q.2d 1715, at*14 (T.T.A.B. 2007) (finding that the survey evidence showing seventy-three percent unaided recognition of BIG GULP was sufficient to meet the high level of fame required under TDRA); Gen. Motors Co. v. Urban Gorilla, LLC., No. 2:06-CV-00133 BSJ, 2010 WL 5395065, at*5 (D. Utah Dec. 27, 2010) (noting that "over $71 \%$ of participants were able to produce the names GM or Hummer when shown an image of a boxy, military-style vehicle" and finding that the survey evidence together with extensive advertising efforts in the amount of hundreds of millions of dollars and large amount of revenue generated of over $\$ 2$ billion support a finding of Hummer as a famous trademark). But see Nissan Motor Co. v. Nissan Computer Corp., 378 F.3d 1002, 1014 (9th Cir. 2004) (ruling that survey evidence of sixty-five percent of the attitude of people who intended to purchase a new car recognized the NISSAN trademark coupled with promotional expenditures of \$898 million during the period 1985-91 were not conclusive to support "as a matter of law" at 
This bright-line requirement of a high percentage of recognition of a mark through survey evidence is consistent with the intent of the statute that only a very few marks deserve such broad, property-like, antidilution protection. ${ }^{209}$ It is also consistent with trademark jurisprudence that in the likelihood of confusion or trademark infringement actions, it is not necessary to submit consumer recognition survey evidence in order to receive a low level of protection compared to broad antidilution protection. ${ }^{210}$

The survey cannot be a typical brand awareness study. For example, consider a measure of brand awareness among whiskey drinkers for brands like Bacardi, Jack Daniels, Jim Beam, Cuervo, Absolute, and others. The result from a brand awareness study is merely a marketing survey or a study of the awareness of brands within a niche. ${ }^{211}$ In other words, this type of brand awareness study is for a company to strategize its marketing plan; it is not a substitute for the actual recognition of the trademark from the overall general consuming public across the United States as a source identifier of the plaintiff's goods or services. ${ }^{212}$ Essentially, the fame survey is for dilution litigation purposes, ${ }^{213}$ not for a marketing campaign. ${ }^{214}$

summary judgment that the NISSAN trademark was famous as of 1991).

209 Under the old trademark dilution statutes, some commentators have advocated for a lower percentage. McCarthy, for example, recommends that a plaintiff's mark must be known by more than fifty percent of the defendant's potential customers in order to be considered "famous." $4 \mathrm{~J}$. THOMAS MCCARTHY, MCCARTHY ON TRADEMARKS AND UNFAIR COMPETITION $§ 24: 92$, at 24 164 (4th ed. 1999); see also Xuan-Thao N. Nguyen, The New Wild West: Measuring and Proving Fame and Dilution Under the Federal Trademark Dilution Act, 63 ALB. L. REV. 201, 234 (1999) (advocating a forty percent rate of recognition among defendant's potential customers in a nationwide survey).

210 See Hainline v. Vanity Fair, Inc., 301 F. App’x 949, 954 (Fed. Cir. 2008) (“Direct evidence of fame, for example from widespread consumer polls, rarely appears in contests over likelihood of confusion. Instead, our cases teach that the fame of a mark may be measured indirectly, among other things, by the volume of sales and advertising expenditures of the goods traveling under the mark, and by the length of time those indicia of commercial awareness have been evident." (emphasis added) (quoting Bose Corp. v. QSC Audio Prods., Inc., 293 F.3d 1367, 1371 (Fed. Cir. 2002))).

211 Maker's Mark Distillery, Inc. v. Diageo N. Am., Inc., 703 F. Supp. 2d 671, 699 (W.D. Ky. 2010) (finding that the plaintiff's trademark is not widely known among the general consuming public because the name is recognized by sixty-nine percent among whisky drinkers).

212 Courts have long distinguished the differences between a brand awareness study from a trademark recognition survey. See Loctite Corp. v. Nat'1 Starch \& Chem. Corp., 516 F. Supp. 190, 206 (S.D.N.Y. 1981) (distinguishing a brand awareness study from a trademark recognition survey by noting that marketing surveys conducted before litigation were designed to test for brand awareness, whereas the "single issue at hand ... [was] whether consumers understood the term 'Super Glue' to designate glue from a single source").

213 Some courts, such as the Ninth Circuit, are known for not according weight to surveys conducted not for the litigation at issue. See Robert H. Thornburg, Trademark Survey Evidence: Review of Current Trends in the Ninth Circuit, 21 SANTA ClARA COMPUTER \& HigH TECH. L.J. 715, 721 (2005) (noting that the Ninth Circuit routinely does not accord weight to surveys conducted for non-litigation purposes or for another case).

214 See Shari Seidman Diamond, Reference Guide on Survey Research, 869 PLI/Pat 329, 341 
Evidence of volume of sales, advertising expenditures, and geographical reach continues to be required for fame analysis. The indirect evidence, however, should not be a substitute for consumer survey evidence proving at least seventy percent of the general consuming public recognition of the mark. Indirect evidence alone has been rejected by courts, even under the old statute, as insufficient to establish fame recognition. ${ }^{215}$

\section{CONCLUSION}

The desire to protect fame acquired and possessed by a trademark through years of investments in advertisements, expansive uses, and enforcement is consistent with the public fascination with fame. Trademark jurisprudence strongly favors the protection of the consumer, not trademark owners. Bestowing property-like protection to trademarks requires concrete proof of national fame through a proper consumer survey evidencing at least seventy percent of the general consuming public across the United States recognizes the trademark. The heightened requirement of national fame strikes a reasonable balance between the interests of trademark owners and the public.

(2006) ("Surveys not conducted specifically in preparation for, or in response to, litigation may provide important information, but they frequently ask irrelevant questions or select inappropriate samples of respondents for study.").

215 TCPIP Holding Co. v. Haar Commc'ns, Inc., 244 F.3d 88, 99-100 (2d Cir. 2001). The court stated in TCPIP Holding that:

We do not believe TCPIP's submissions to the district court demonstrated the degree of fame necessary to qualify. The submissions were quite sketchy. According to TCPIP's affidavit, in 1999 it operated 228 retail stores in 27 states under the mark "The Children's Place," and achieved sales in 1998 of $\$ 280$ million, having grown from $\$ 100$ million in sales though 87 stores in 1994. Over the past decade, the affidavit asserts, TCPIP spent "tens of millions of dollars" advertising its mark, but does not tell how many millions, when expended, or how effectively. Nor did TCPIP submit consumer surveys, press accounts, or other evidence of fame. The affidavit gives no statistics of any kind pertaining to any year earlier than 1994. While it asserts that the plaintiff (and its predecessors) have used the mark continuously and exclusively for thirty years, it gives no further information-apart from unsubstantiated conclusory phrases like "the mark The Children's Place has been widely recognized by American consumers" - that would enable a court to determine the extent or dimension of public recognition of the mark and whether it has fame sufficient to meet the requirement of the Act. While the information given undoubtedly shows considerable commercial success and growth, the aggregate sales under the mark since it originated (which have not been furnished to us) may well not equal the sales of Dupont, Buick, or Kodak in Id. any given month. 